\title{
Three new species of eriophyoid mites (Acariformes, Eriophyoidea) from Lippia alba (Verbenaceae) from Brazil, and remarks on the thorn-like spermathecal process
}

Author(s): Mércia E. Duarte, Philipp E. Chetverikov, Edmilson S. Silva \& Denise Navia

Source: Systematic and Applied Acarology, 21(9):1225-1249.

Published By: Systematic and Applied Acarology Society

URL: http://www.bioone.org/doi/full/10.11158/saa.21.9.7

BioOne (www.bioone.org) is a nonprofit, online aggregation of core research in the biological, ecological, and environmental sciences. BioOne provides a sustainable online platform for over 170 journals and books published by nonprofit societies, associations, museums, institutions, and presses.

Your use of this PDF, the BioOne Web site, and all posted and associated content indicates your acceptance of BioOne's Terms of Use, available at www.bioone.org/page/terms of use.

Usage of BioOne content is strictly limited to personal, educational, and non-commercial use. Commercial inquiries or rights and permissions requests should be directed to the individual publisher as copyright holder. 


\title{
Three new species of eriophyoid mites (Acariformes, Eriophyoidea) from Lippia alba (Verbenaceae) from Brazil, and remarks on the thorn-like spermathecal process
}

\author{
MÉRCIA E. DUARTE ${ }^{1 *}$, PHILIPP E. CHETVERIKOV ${ }^{2,3}$, EDMILSON S. SILVA $^{1,5} \&$ DENISE \\ NAVIA $^{4}$ \\ ${ }^{1}$ Universidade Federal de Alagoas, Centro de Ciências Agrárias - CECA; Rio Largo, Alagoas 57100-000; Brazil. \\ ${ }^{2}$ Department of Invertebrate Zoology, Saint-Petersburg State University, Universitetskaya nab., 7/9, 199034, St. Petersburg, \\ Russia. \\ ${ }^{3}$ Zoological Institute, Russian Academy of Sciences, Universitetskaya nab., 1, 199034 St. Petersburg, Russia. \\ ${ }^{4}$ Embrapa Recursos Genéticos e Biotecnologia; Brasília, Distrito Federal 70.770-900; Brazil. \\ ${ }^{5}$ Universidade Federal de Alagoas, Campus Arapiraca, Arapiraca, Alagoas 57309-005; Brazil. \\ *Corresponding author.E-mail: mercia_elias@hotmail.com.
}

\begin{abstract}
Three new vagrant species of eriophyoid mites living on the lower leaf surface of Lippia alba (Mill.) N. E. Brown (Verbenaceae) in the Northeast and Center West Brazil, are described and illustrated. They are: Paraphytoptus serenus sp. nov. and Tegoprionus alobus sp. nov. (both from family Eriophyidae) and Rhynacus lippius sp. nov. (Diptilomiopidae). Detailed anatomy of internal genitalia of the representatives of the three eriophyoid genera (Rhynacus, Paraphytoptus and Tegoprionus) was studied and described for the first time. A new, previously neglected genital structure of eriophyoids, the thorn-like spermathecal process, has been discovered with the aid of confocal laser scanning microscopy. Preliminary analysis indicates that this structure is common for many eriophyid and diptilomiopid species, however it is absent in phytoptid mites. The hypothesis that presence/absence of this process separate contemporary families of Eriophyoidea (Phytoptidae and Eriophyidae+Diptilomiopidae) needs further testing.
\end{abstract}

Key words: Confocal microscopy, Diptilomiopinae, Aceriini, Anthocoptini, Neotropical, reproductive anatomy.

\section{Introduction}

Eriophyoidea is a group of phytoparasitic mites encounting about 5000 species in three families (Amrine et al. 2003). Up to now only 223 species of eriophyoid mites inhabiting 191 host plants distributed in 58 plant families have been recorded in Brazil. Among them around 70\% were originally described from the country. Most of species are known from the Southern and Northeastern States of Brazil, still remaining many extensively unexplored areas containing a huge and diverse set of vegetal taxa (Navia et al. 2014).

Lippia alba (Mill.) N. E. Brown (Verbenaceae) is a native aromatic shrub that is widely found all over South America, Central America and Caribbean (Lemos et al. 1990, Martins et al. 1995) and is commonly known as 'bushy lippia'. This plant is widely cultivated in Brazil, where it is commonly known as "erva cidreira". It has high pharmacological importance and is used in folk medicine (Aguiar 2008). The analgesic, gastrointestinal and tranquilizing actions are popularly attributed to the tea from its leaves (Vale et al. 1999). 
Up to now no eriophyoid mites have been recorded from Lippia. In the course of faunistic survey in Brazil in 2012 by the first author, chlorotic spots on leaves of Lippia alba were found. After examination of the plant samples in the laboratory three new eriophyoid species were found. In this paper we aimed: 1) to provide detailed descriptions of females and males of these three new species 2) to study the anatomy of female internal genitalia of the new species using CLSM and 3) to compare the results with previous data on genital anatomy of eriophyoids from literature.

\section{Materials and methods}

Collecting, classification and morphological measurements

Eriophyoid mites were collected from leaves of L. alba (Verbenaceae) in three localities in Brazil: Maceió and Maribondo, Alagoas State, Northeastern Region; and in Brasília, Federal District, Center West Region; in all localities samples were collected from cultivated plants in urban areas.

The mites were collected by direct examination under a dissecting stereomicroscope Nikon SMZ1000 in laboratory and preserved in a vial containing $70 \%$ ethanol. The specimens were later transported to Russia for further examination. In the Laboratory of Parasitology of Zoological Institute of RAS (Russia) the mites were transferred into Petri dishes and mounted in modified Hoyer's medium (Dobrivojević \& Petanović 1982) under a dissecting stereomicroscope MBS10 LOMO. The slide mounted specimens were cleared on a heating block (at $80^{\circ} \mathrm{C}$ for 5-7 hours).

Terminology of external morphology follow that of Lindquist (1996) and classification is based on Amrine et al. (2003). Measurements are given in micrometers $(\mu \mathrm{m})$ and, unless stated otherwise, refer to the length of the structure. All measurements were taken with a $100 \mathrm{x}$ objective. In the description of the female, each measurement of the holotype precedes the corresponding range for the paratypes. When no variation was observed among measurements it will be indicated with "*”". In addition, the mean, standard deviation and ranges of measurements of all studied specimens (paratype females and males) are given in Table 4. Some measurements of the holotype or paratypes could not be taken because of the positions in which the specimens were mounted. The count of ventral opisthosomal annuli starts from the first full annulus behind the genitalia. Dorsal opisthosomal annuli were counted from the first full annulus behind the middle of the prodorsal shield rear margin. When the length of cheliceral stylets is not given, it means that it was not possible to measure this character, since they were in a bundle that was immersed with other gnathosomal structures. Measurements were conducted according to de Lillo et al. (2010) except for the following: 1) the body length, which was measured from the tip of the frontal lobe to the rear end of the anal lobe, not considering pedipalps; 2) the $s c$ tubercles space measurement (distance between the tubercles, not between $s c$ setae); 3) empodium length, which includes its basal portion inserted into the tarsus.

Three different light microscopy techniques (PC LM-phase contrast, DIC LM-differential interference contrast and CLSM-confocal laser scanning microscopy) were used for studying morphology of eriophyoid mites. The external morphology was studied under PC LM and DIC LM using a Leica DM4000 B (under HCX PL Fluotar 100x/1.30 oil DIC objective) compound microscope equipped with a digital microscope camera (Leica DFC365 FX) connected to computer. The measurements (all in micrometres, $\mu \mathrm{m}$ ) and micrographs were obtained using Micro-manager 1.4 Software.

CLSM acquisition was carried out using Spectral confocal and multiphoton system Leica TCS SP2 with objectives 63X N.A. 1.4-0.60 Oil lBL HCX PL APO and 40X N.A. 1.25-0.75 Oil CS HCX PL APO at an excitation wavelength of $405 \mathrm{~nm}$ with the same adjustments of confocal microscope as described by Chetverikov (2012). Between 18 and 54 optical slices were recorded from 30 
paratype females and 2 paratype male from Paraphytoptus serenus sp. nov., 7 paratype females and 1 paratype male from Tegoprionus alobus sp. nov. and 22 paratype females and 1 paratype male from Rhynacus lippius sp. nov.. The digital images of the confocal stacks and the measurements of internal genital apodemes, spermathecal tubes and spermathecae were processed using Fiji-win3220091014 Open Source Image Processing Package, to obtain maximum intensity and were checked for brightness and contrast correction with Photoshop CS2 version 9.0 (Adobe Systems). Measurement methods and terminology of the internal genitalia elements follow the protocols described in Chetverikov et al. (2012, 2014a, b) and Chetverikov (2014). The angles between spermatheca and longitudinal bridge (SB), spermathecal tube and spermatheca (ST) and spermathecal tube and longitudinal bridge (TB) (see details in the Chetverikov et al. (2014b)) were measured and are given in Table 5.

\section{Taxonomy \\ Family Diptilomiopidae Keifer 1944 \\ Subfamily Diptilomiopinae Keifer 1944 \\ Genus Rhynacus Keifer 1951}

Diagnosis. Diptilomiopine mites (sensu Amrine et al. 2003) with idiosoma spindleform, robust; shield wider than long, without anterior lobe over the base of gnathosoma; scapular tubercles minute, situated ahead of rear shield margin, scapular seta (sc) missing. Coxae I separated by a ridge; setae $1 b$ of coxae I missing. All leg segments present; legs I and II lacking ventral basifemoral setae ( $b v)$; antaxial genual seta $\left(l^{\prime \prime}\right)$ on leg II absent. Opisthosoma subcircular in cross section, with at most a slight subdorsal furrow; lateral seta $c 2$ missing; dorsal annuli not much less numerous than ventral ones.

Remarks. Contrary to all other Rhynacus spp., the new species R. lippius sp. nov. lacks dorsal pedipalp genual seta $(d)$. Absence of this seta is quite rare among eriophyoids. As far as we know, it is absent in a single phytoptid genus Novophytoptus (Roivainen 1947, Chetverikov 2015), and in representatives of several eriophyid and diptilomiopid genera (e.g. in Neodicrothrix rutacevagrans Umapathy 1999 (Chandrapatya et al. 2014), and Diptilomiopus vitisis (Wang et al. 2009). Possibly, the genus Rhynacus could be divided into two subgenera based on presence/absence of seta $d$, and may be these two subgenera will be proved to constitute different genera in future. Other possibility is that this seta constitutes a specific character, without importance to the generic classification.

Rhynacus lippius sp. nov. Duarte, Chetverikov \& Navia (Figs. 1-3 and 10 A, B, Tables 1, 4 and 5)

Description. Female $(\mathrm{n}=10)$. Idiosoma vermiform, 288 (246-299) long, 75 (65-82) wide, yellowish. Gnathosoma 40 (35-48) long, projecting downwards; pedipalp coxal seta (ep) 1 (1-2) long; dorsal pedipalp genual seta $(d)$ absent, subapical pedipalp tarsal seta $(v) 3(2-4)$ long; chelicerae 70 (67-74) long, auxilary stylet 56 (53-60); suboral plate granulated and anteriorly rounded. Prodorsal shield 28 (24-28) long, 50 (44-53) wide, semioval; scapular tubercles minutes ahead of rear shield margin, 23 (22-25) apart, scapular setae ( $s c$ ) absent. Shield ornamentation. Distinct sinuous lines forming cells present on the shield. Median line complete, admedian lines connected to median line by three diagonal lines forming three closed cells on each side, submedian region with cells varying from subrectangular to semicircular; in some species these submedian cells can be open or closed; epicoxal area (sensu Chetverikov \& Craemer 2015) with tiny microtubercles. Coxigenital region with 3 (2-3) incomplete annuli and 3 (2-3) complete annuli, microtuberculated. Coxisternal plates with some short dashes and granulations; prosternal apodeme 10 (9-13) long, 
anterior seta on coxisternum I ( 1 b) absent; proximal seta on coxisternum I (1a) 31 (26-35) long, 11 (11-14) apart; proximal seta on coxisternum II (2a) 66 (54-67) long, 27 (22-32) apart. Leg I 40 (3541) long, femur 8 (8-10); genu 5 (5-7), antaxial genual seta $\left(l^{\prime \prime}\right) 37$ (30-38); tibia 8 (6-8), paraxial tibial seta $\left(l^{\prime}\right) 2(1-3)$; tarsus 11 (9-12), antaxial fastigial tarsal seta $\left(f t^{\prime \prime}\right) 34$ (29-36), paraxial fastigial tarsal seta $\left(f t^{\prime}\right) 30$ (27-33), paraxial unguinal tarsal seta $\left(u^{\prime}\right) 6(5-7)$, tarsal empodium 9 (8-10) long, divided, 6 (5-6)-rayed in each branch, tarsal solenidion ( $\omega) 7$ (6-7), slightly curved. Leg II 36 (3236) long, femur 9 (7-9); genu 3 (3-5); tibia 6 (5-6); tarsus 10 (10-13), antaxial fastigial tarsal seta $\left(f t^{\prime \prime}\right) 35$ (32-36), paraxial fastigial tarsal seta $\left(f t^{\prime}\right) 7$ (7-10), paraxial unguinal tarsal seta $\left(u^{\prime}\right) 5(5-7)$, tarsal empodium 8 (8-10) long, divided, 6 (5-6)-rayed in each branch, tarsal solenidion ( $\omega) 9(7-9)$, slightly curved with flat knob. Opisthosoma with 82 (77-84) dorsal annuli bearing small elongated microtubercles, telosomal annuli with smaller microtubercles dorsally; 77 (71-81) ventral annuli bearing cone-shaped pointed microtubercles, telosomal annuli (after seta $f$ ) with elongated microtubercles. Seta $d 87$ (79-93) long; 62 (49-62) apart; on ventral annulus 16-17 (16-20); seta $e$ 13 (10-16) long, 38 (35-41) apart, on ventral annulus 33-35 (31-40); seta f39 (37-45) long, 29 (2430) apart, on ventral annulus 65 (61-71). Seta $h_{1} 1(1) ; h_{2} 89$ (79-99). External genitalia. Genital coverflap with 8 (7-9) short irregular dashes (lines), 24 (22-25) long, 27 (25-29) wide, basally granulated, setae $3 a 9$ (9-11) long.

TABLE 1. Main morphological differences among Rhynacus species

\begin{tabular}{|c|c|c|c|c|c|}
\hline Characters & $\begin{array}{l}\text { Rhynacus lippius } \\
\text { sp. nov. }\end{array}$ & $\begin{array}{c}\text { Rhynacus arctostaphyli } \\
\text { Keifer } 1938\end{array}$ & $\begin{array}{l}\text { Rhynacus abronius } \\
\text { Keifer 1939b }\end{array}$ & $\begin{array}{c}\text { Rhynacus kraussii Keifer } \\
1962\end{array}$ & $\begin{array}{l}\text { Rhynacus acerioides } \\
\text { Flechtmann } 2014\end{array}$ \\
\hline $\begin{array}{l}\text { Ornamentation of } \\
\text { genital coverflap }\end{array}$ & Short dashes & Smooth & Short dashes & Strong longitudinal ribs & Smooth \\
\hline $\begin{array}{l}\text { Number of empodial } \\
\text { rays }\end{array}$ & $5-6$ & 7 & 6 & $6-7$ & 5 \\
\hline $\begin{array}{l}\text { Length of prodorsal } \\
\text { shield }\end{array}$ & 26 & 25 & 34 & 28 & $27-33$ \\
\hline $\begin{array}{l}\text { Opisthosomal } \\
\text { forrows/ridges }\end{array}$ & $\begin{array}{l}\text { Faint middorsal } \\
\text { anterior ridge }\end{array}$ & $\begin{array}{l}\text { Middorsal anterior } \\
\text { ridge }\end{array}$ & $\begin{array}{l}\text { A shallow furrow on } \\
\text { each side }\end{array}$ & Middorsal anterior ridge & $\begin{array}{c}\text { Faint middorsal anterior } \\
\text { ridge }\end{array}$ \\
\hline Scapular tubercles & Present & Present & Present & Present & Absent in adults \\
\hline $\begin{array}{l}\text { Dorsal pedipalp } \\
\text { genual seta }(d)\end{array}$ & Absent & Present & Present & Present & Present \\
\hline Seta $h l$ & Present & Present & Absent & Absent & Present \\
\hline
\end{tabular}

Male $(n=2)$. Smaller than females and similar in shape to them. All measurements of males are given in Table 4. External genitalia. Subtriangular, 20-22 wide, setae 3a 7-8 long. Posterior part of the epiandrium (external genitalia), between and behind setae $3 a$, with irregular rounded microtubercles (Figs. 2 and 3 E, F).

Host plant. Lippia alba (Mill.) N. E. Brown (Verbenaceae). Mites are vagrant on the lower leaf surface. Presumably associated with chlorotic spots.

Type material. Female holotype, female paratypes, 6 males (each on a separate slide), deposited in the mite collection at Embrapa Genetic Resources and Biotechnology, Brasilia, Federal District, Brazil. Paratypes: 6 females, 1 males (each on a separate slide), deposited in the Department of Entomology, Plant Pathology and Agricultural Zoology, ESALQ/USP, Piracicaba, São Paulo, Brazil and 10 females, 2 males (each on a separate slide) in the Acarological Collection of the Zoological Institute of Russian Academy of Sciences (ZIN RAS), Russia. All specimens from Brazil: Maribondo, Alagoas State (09 34' 38"S, 36 18' 10" O), 22 April 2014, and Brasília, Federal District (15 41' 18"S, 47 49' 39" O), 03 March 2014, coll. Duarte, M.E. and Santos M. D. 

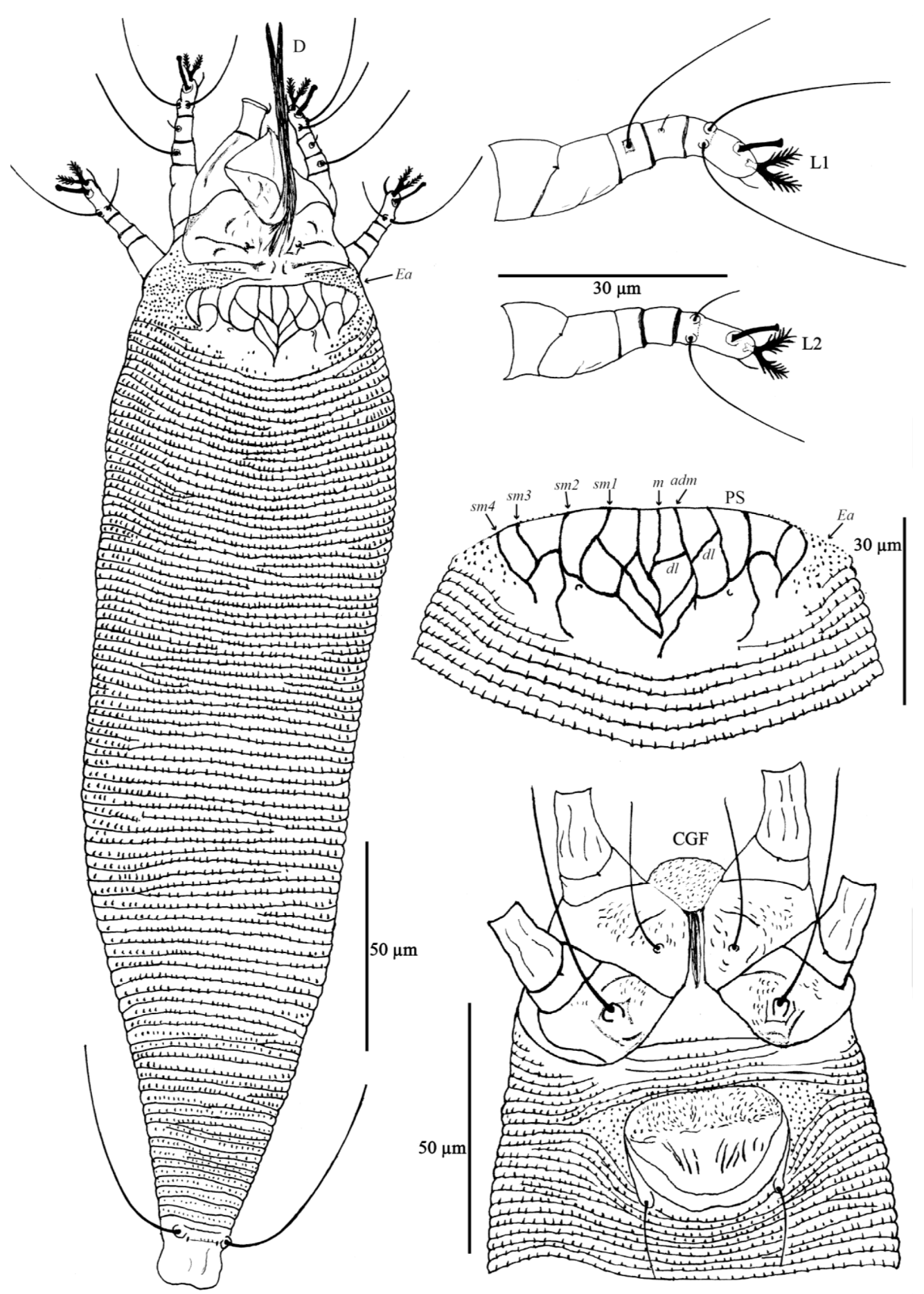

FIGURE 1. Rhynacus lippius sp. nov.-D. Female dorsal view; L1. Leg I, female; L2. Leg II, female; PS. Prodorsal shield; CGF. Coxigenital region, female. Notations: EA-epicoxal area; $a d m$-admedian line; $d l$ diagonal line; m-median line; sm1-4-submedian lines 1 to 4 correspondingly. 


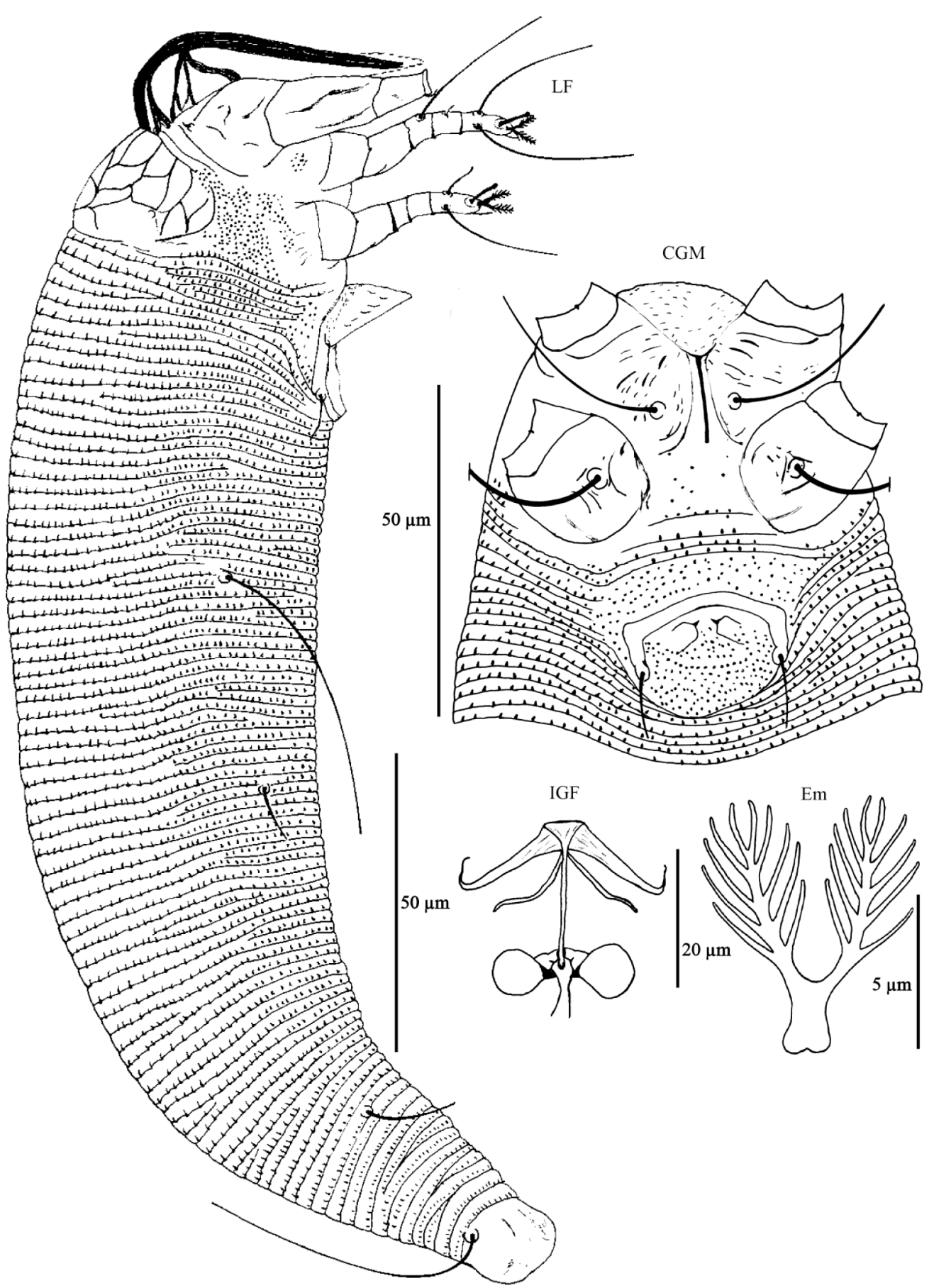

FIGURE 2. Rhynacus lippius sp. nov.-LF. Lateral view, female; CGM. Coxigenital region, male; Em. Empodium; IGF. Internal genitalia, female.

Additional material. 22 mites on 11 slides collected from Brazil: Maceió, Alagoas State (09 32' 42"S, 35 43' 31" O), 23 May 2012 and 12 October 2013 (same host and collector). All deposited in the mite collection at Embrapa Genetic Resources and Biotechnology, Brasılia, Federal District, Brazil. 

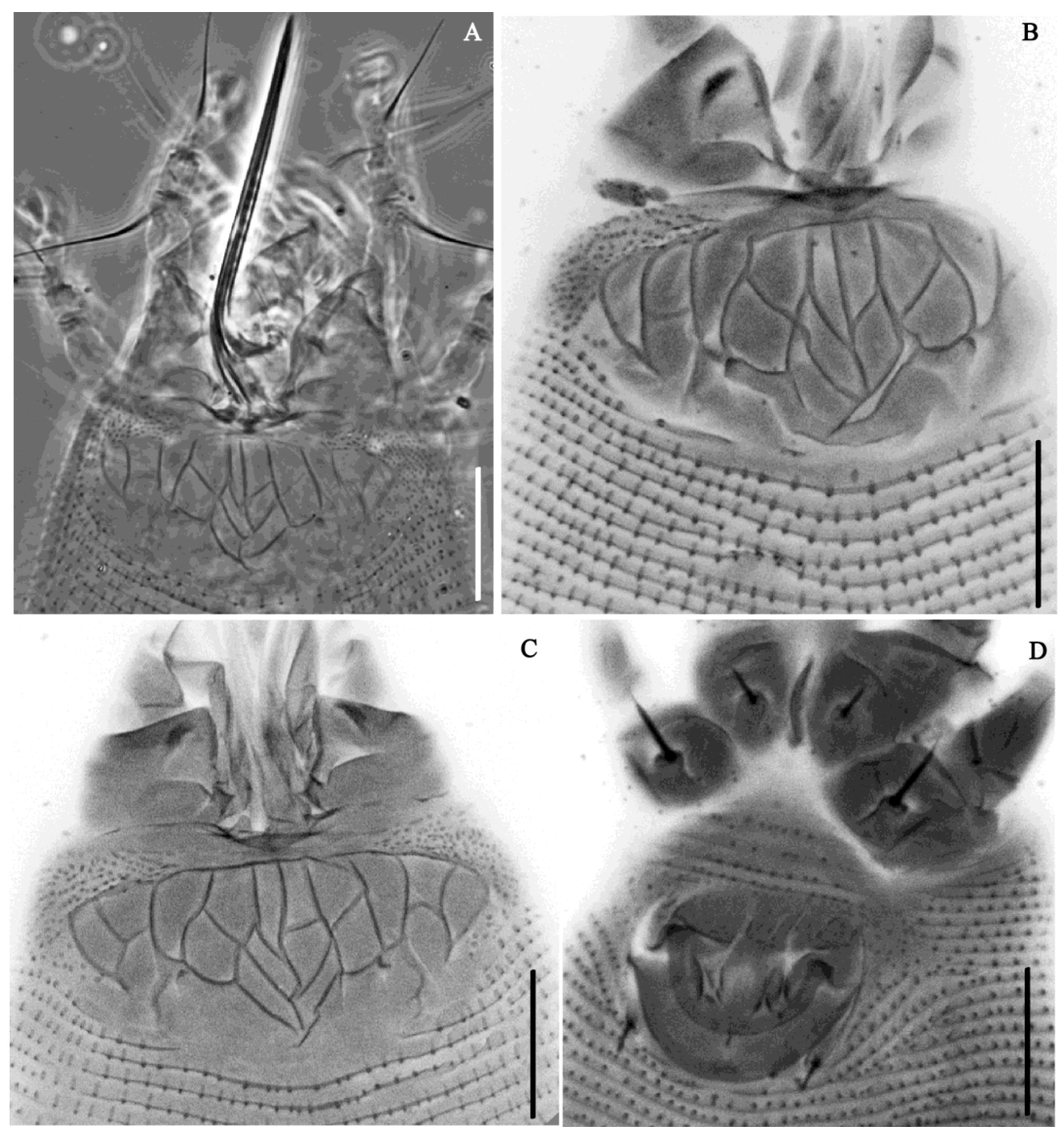

$\mathrm{C}$
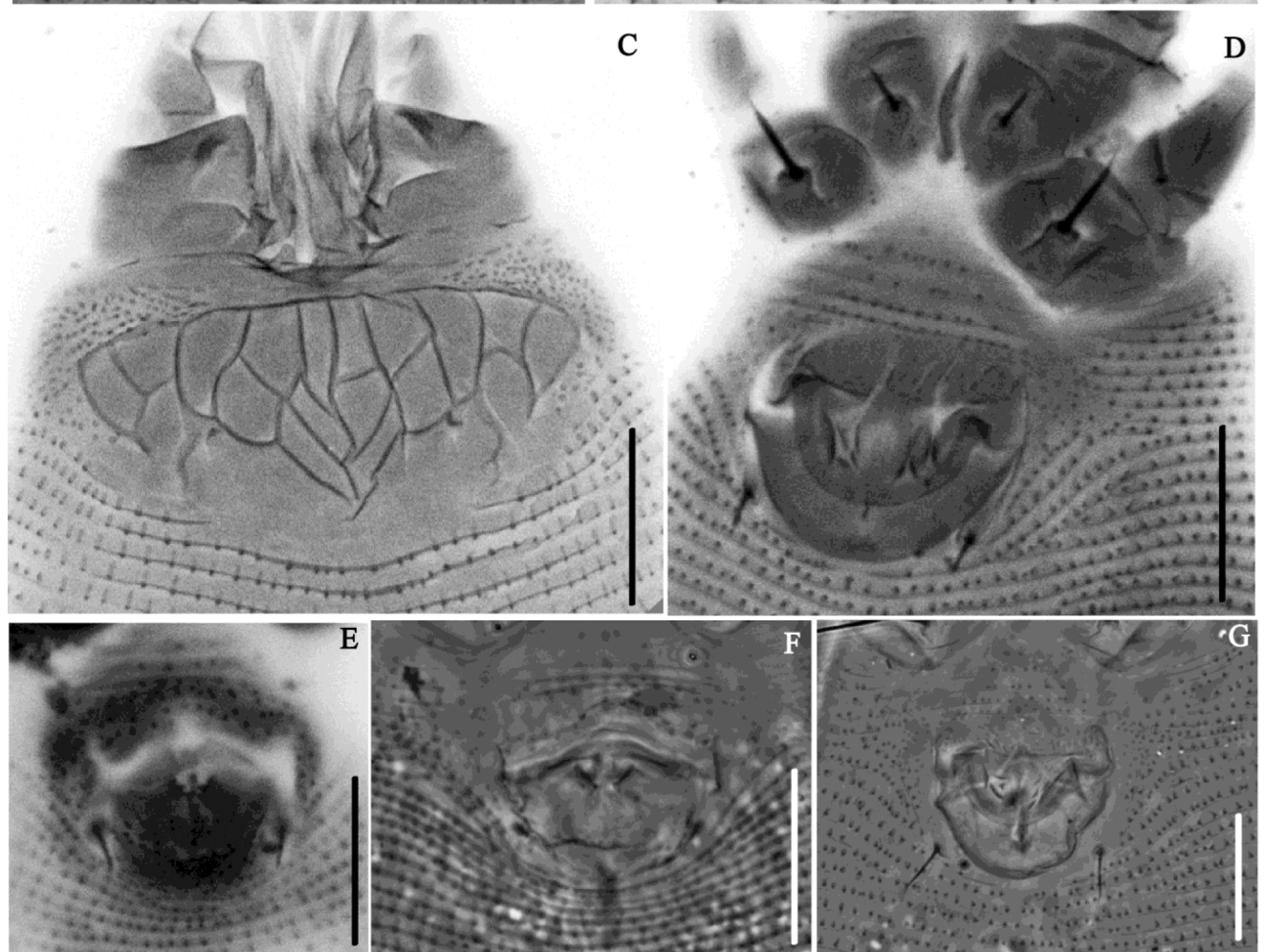

FIGURE 3. PC LM (A, F and G) and CLSM autofluorescent (B-E) images of Rhynacus lippius sp. nov. (AC) prodorsal shield; (D) coxigenital region, female, (E, F) external genitalia, male, (G) external genitalia, female. Scale bar: $20 \mu \mathrm{m}$.

Etymology. The specific designation is an adjective, gender masculine, derived from the generic name of the host plant, Lippia.

Differential diagnosis. Rhynacus lippius sp. nov. is morphologically close to Rhynacus kraussii Kifer 1962, which also inhabits a South American verbenaceous plant, Lantana camara L., 
and was described from Colombia. These two species differ in ornamentation of genital coverflap (the coverflap with short irregular dashes in the new species and about 12 distinct longitudinal ribs in $R$. kraussii), in the ornamentation of femora I and II, (femora with curved lines on the lower surfaces in the new species and apparently smooth in $R$. kraussii), in the number of empodial rays (5-6 rays in the new species and 6-7 rays in $R$. kraussii), in the presence/absence of seta $h l$ (minute acessory seta $h l$ present in the new species whereas in $R$. kraussii it is absent), and in the size of dorsal microtubercles (smaller dorsal microtubercles in the new species and apparently larger and more elongated in $R$. kraussii).

Remarks. The new species is the 5th species in the genus Rhynacus. It can be distinguished from other species of this genus based on the following characters: ornamentation of genital coverflap, number of empodial rays, length of prodorsal shield, presence/absence of opisthosomal forrows and ridges, dorsal pedipalp genual seta $(d)$ and opisthosomal seta $h l$ (Table 1).

\section{Family Eriophyidae Nalepa 1898 \\ Subfamily Eriophyinae Nalepa 1898 \\ Tribe Aceriini Amrine and Stasny 1994 \\ Genus Paraphytoptus Nalepa 1896}

Diagnosis. Frontal lobe of prodorsal shield absent or very small. Anterior part of the opisthosoma, with annuli narrow and subequal dorsoventrally; posterior part of the opisthosoma with wider dorsal annuli covering three or four narrow ventral annuli.

Paraphytoptus serenus sp. nov. Duarte, Chetverikov \& Navia (Figs. 4-6 and 10 C-E, Tables 2, 4 and 5)

Description. Female $(\mathrm{n}=10)$. Idiosoma fusiform, 195 (172-215) long, 53 (48-59) wide, whitish. Gnathosoma 18 (16-19) long, projecting downwards; pedipalp coxal seta (ep) 2 (2)*, dorsal pedipalp genual seta $(d) 3$ (3-4); chelicerae 17 (16-18) long; auxiliary stylet 14 (10-14) long. Prodorsal shield 28 (27-29) long, 39 (31-39) wide, sub-semicircular; median line incomplete, faint, present in rear part of prodorsal shield only or even not visible in some specimens; admedian lines indistinct anteriorly, going parallel to each other in the median part of prodorsal shield and diverging in near rear shield margin; submedian lines broken and curved; epicoxal area (sensu Chetverikov and Craemer 2015) with dashes and granulations; frontal lobe short, $2 *$ long, 8 (6-8) wide; scapular tubercles on rear shield margin, 14 (14-16) apart, scapular setae (sc) 18 (17-19) long, directed backward and diverging, reaching the 5th (5-6) dorsal annulus. Subcapitular plate with dashes and granulations. Coxigenital region with $2(1-2)$ incomplete annuli and 3 (2-3) complete annuli and, microtuberculate. Coxisternal plates with dashes and granulations, prosternal apodeme 8 (6-8) long, anterior seta on coxisternum I (1b) 7 (7-10) long, 8 (7-9) apart; proximal seta on coxisternum I (1a) 22 (18-24) long, 9 (8-11) apart; proximal seta on coxisternum II (2a) 34 (31-39) long, 22 (20-24) apart. Leg I 25 (22-25), femur 5 (5-6), ventral basifemoral seta (bv) 9 (7-9); genu $4 *$, antaxial genual seta $\left(l^{\prime \prime}\right) 19(15-21)$; tibia $5(4-5)$, paraxial tibial seta $(l) 4(3-4)$; tarsus $6(5-7)$, antaxial fastigial tarsal seta $\left(f t^{\prime \prime}\right) 20$ (19-22), paraxial fastigial tarsal seta $\left(f t^{\prime}\right) 17$ (14-18), paraxial unguinal tarsal seta $\left(u^{\prime}\right) 4(3-4)$, tarsal empodium 6 (5-6) long, entire, 4-rayed, each ray knobbed distally, tarsal solenidion elongated $(\omega) 14$ (12-15), slightly curved, blunt. Leg II 22 (19-23) long, femur 6 (4-6), ventral basifemoral seta $(b v) 7(6-8)$; genu $3^{*}$, antaxial genual seta $\left(l^{\prime \prime}\right) 7(5-7)$; tibia $4(3-4)$; tarsus $6(4-6)$, antaxial fastigial tarsal seta $\left(f t^{\prime \prime}\right) 20(17-20)$, paraxial fastigial tarsal seta $\left(f t^{\prime}\right)$ 6 (4-6), paraxial unguinal tarsal seta $\left(u^{\prime}\right) 3$ (3-4), tarsal empodium as in leg I, 6 (5-6) long, 4 (4)rayed, tarsal solenidion elongated $(\omega) 13$ (11-14), slightly curved, blunt. Opisthosoma with 33 (33- 
38) dorsal annuli, first 17-20 annuli subequal dorsoventrally, narrower and evenly microtuberculated, followed by 12-15 broader annuli and 3-4 telosomal annuli narrower, both slightly microtuberculate annuli posteriorly; 49 (46-56) ventral annuli. Microtubercles slightly elongated on ventral and anterior dorsal annuli and more elongated and sparse on posterior dorsal annuli. Seta $c 221$ (17-22) long, on ventral annulus 4 (4-5); seta $d 34$ (33-40) long, 38 (38-48) apart, on ventral annulus 15 (15-16); seta $e$ 9 (7-11) long, 22 (21-29) apart, on ventral annulus 28 (28-32); seta $f 19$ (15-19) long, 16 (13-16) apart, on ventral annulus 45 (42-52). Seta $h_{1} 3(3-4), h_{2} 51$ (3352). External genitalia 14 (12-14) long, 20 (18-20) wide, coverflap with 8 (8-9) longitudinal ridges on $3 / 4$ posterior area, basally smooth, genital seta $3 a 14$ (10-14) long.

TABLE 2. Main morphological differences between Paraphytoptus serenus sp. nov. and Paraphytoptus magdalenae Craemer 1996

\begin{tabular}{lcc}
\hline Characters & P. serenus sp. nov. & P. magdalenae Craemer 1996 \\
\hline Length of idiosoma & $172-215$ & $120-152$ \\
Broader posterior annuli ornamentation & Microtuberculate & Smooth \\
Number of ventral annuli & $46-56$ & $54-75$ \\
Coxal plates ornamentation & Some short dashes and slightly granulation & Smooth \\
Scapular tubercles apart & $14-16$ & $19-21$ \\
Length of tarsal solenidion I & $12-15$ & $10-11$ \\
Length of tarsal solenidion II & $11-14$ & $9-10$ \\
\hline
\end{tabular}

Male $(n=5)$. Smaller than females and generally similar to them. The most contrasting differences are the structure of external genitalia. All measurements of males are given in Table 4. External genitalia. Subtriangular, 15-18 wide, seta $3 a$ 8-11 long. Posterior part of the epiandrium (external genitalia), between and behind genital setae $3 a$, with rounded microtubercles aligned in rows or sometimes irregular (Fig. 4 and 6 F).

Host plant. Lippia alba (Mill.) N. E. Brown (Verbenaceae). Mites are vagrant on the lower leaf surface. Presumably associated with chlorotic spots. Type material. Female holotype, 32 female paratypes, 9 males (each on a separate slide) deposited in the mite collection at Embrapa Genetic Resources and Biotechnology, Brasilia, Federal District, Brazil. Paratypes: 10 females, 3 males deposited in the Department of Entomology, Plant Pathology and Agricultural Zoology, ESALQ/ USP, Piracicaba, São Paulo, Brazil and 20 females, 5 males deposited in the Acarological Collection of the Zoological Institute of Russian Academy of Sciences (ZIN RAS), Russia. All specimens from Brazil: Maribondo, Alagoas State $\left(09^{\circ} 34^{\prime} 38^{\prime \prime S}, 36^{\circ} 18^{\prime} 10^{\prime \prime}\right.$ O), 22 April 2014, and Brasília, Federal District (15 41' 18"S, 47 49' 39" O), 03 March 2014, coll. Duarte, M.E., Navia, D. and Santos M. D.

Additional material. 68 mites on 22 slides collected from Brazil: Maceió, Alagoas State $\left(09^{\circ}\right.$ 32' 42"S, 35 43' 31" O), 23 May 2012 and 12 October 2013 (same host), collector Duarte, M.E. All deposited in the mite collection at Embrapa Genetic Resources and Biotechnology, Brasılia, Federal District, Brazil.

Etymology. The specific designation is an adjective, gender masculine, from the Latin word serenus, "calm", referring to the tranquilizing properties of the host plant.

Differential diagnosis. Up to now, only one species of the genus Paraphytoptus ( $P$. magdalenae Craemer 1996 from Lantana camara L.) has been known from verbenaceous plants. 
Paraphytoptus serenus sp. nov. can be differentiated from $P$. magdalenae in the presence of microtubercles on the broader posterior annuli; number of ventral annuli; coxal plates ornamentation; idiosoma length; scapular tubercles apart and length of tarsal solenidion I and II (Table 2).
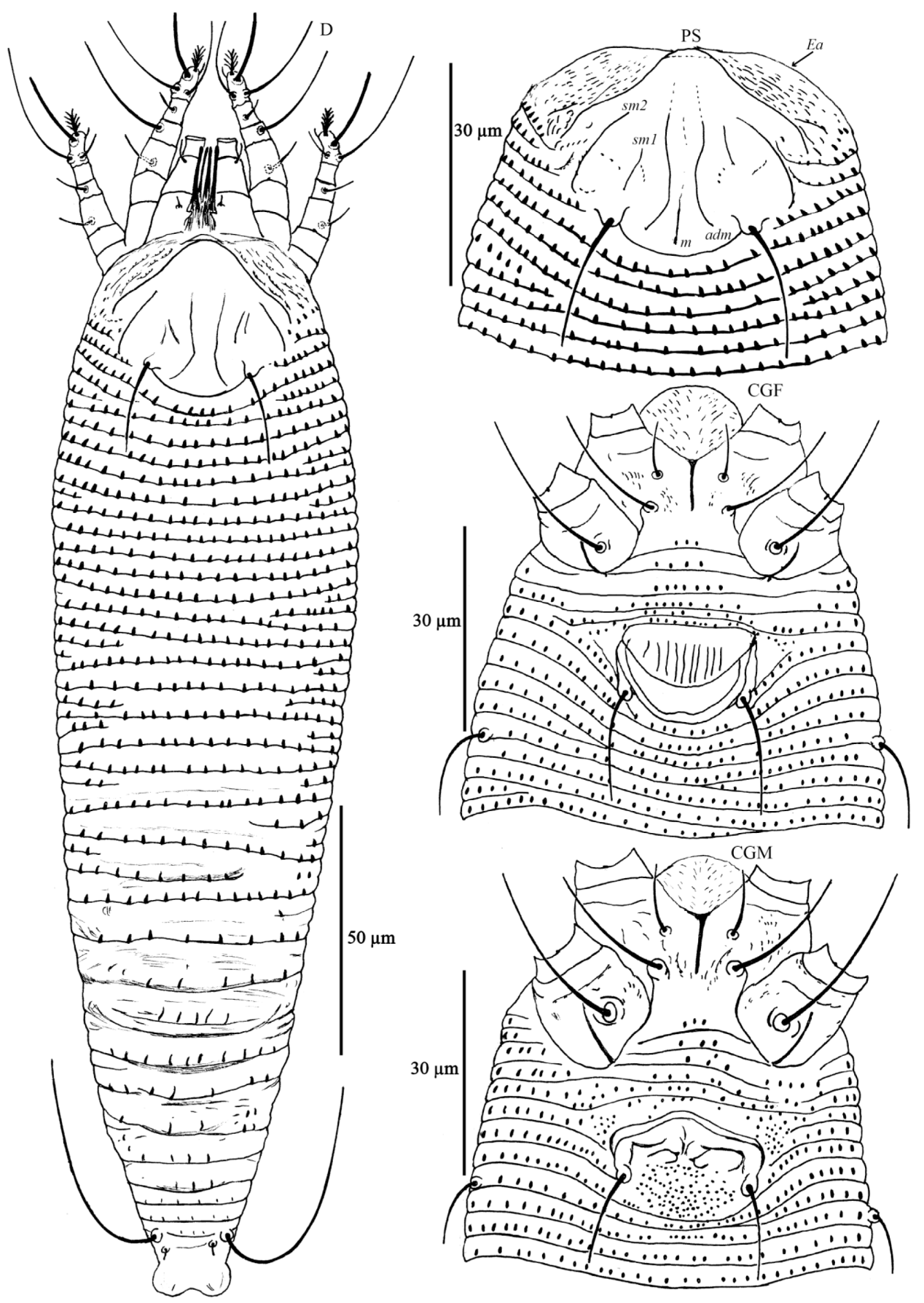

FIGURE 4. Paraphytoptus serenus sp. nov.-D. Female dorsal view; PS. Prodorsal shield; CGF. Coxigenital region, female; CGF. Coxigenital region; male. Notations: $E a$-epicoxal area; $a d m$-admedian line; $m$-median line; sm1-2-submedian lines 1 to 2 correspondingly. 


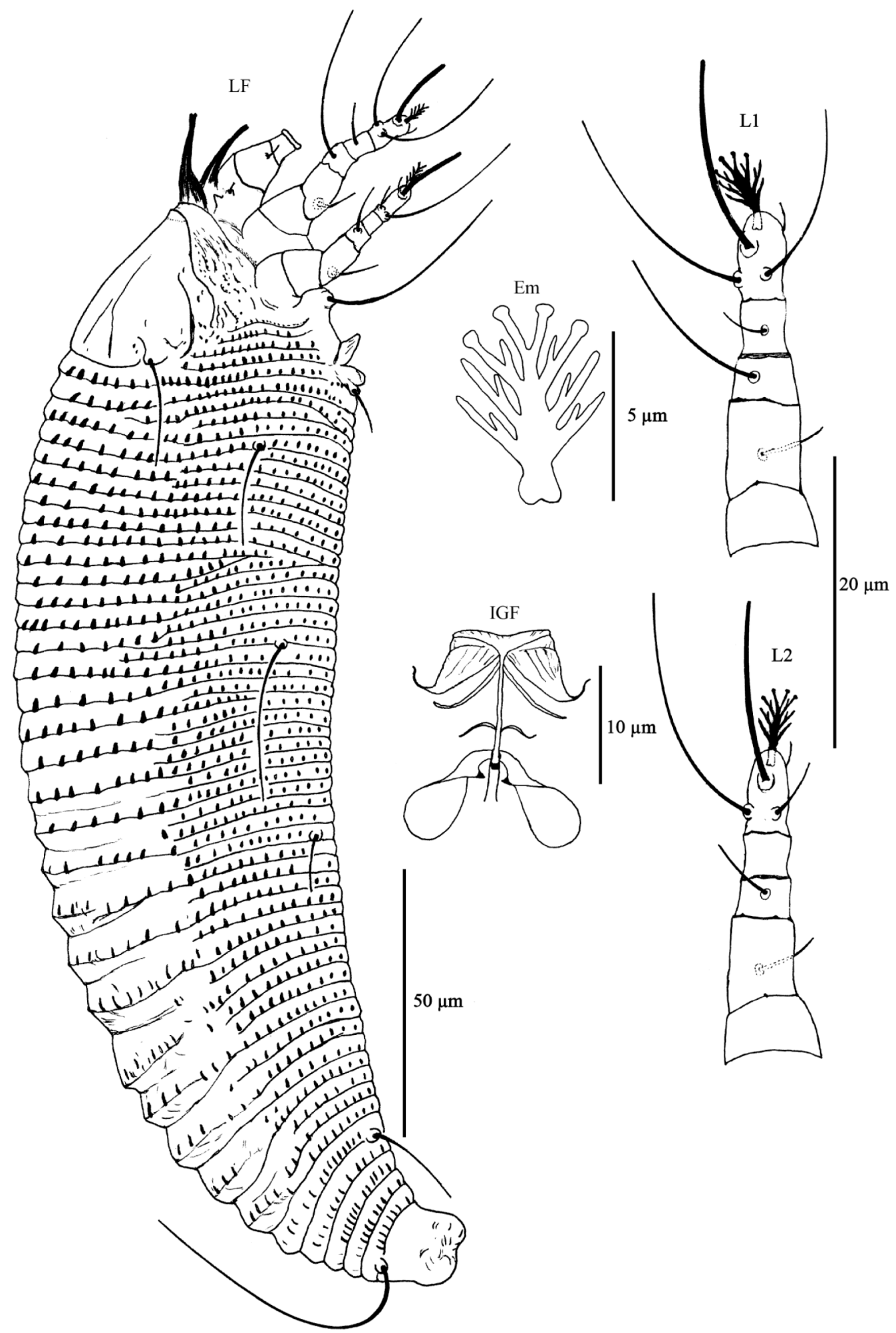

FIGURE 5. Paraphytoptus serenus sp. nov.-LF. Lateral view, female; L1. Leg I, female; L2. Leg II, female; Em. Empodium; IGF. Internal genitalia, female. 

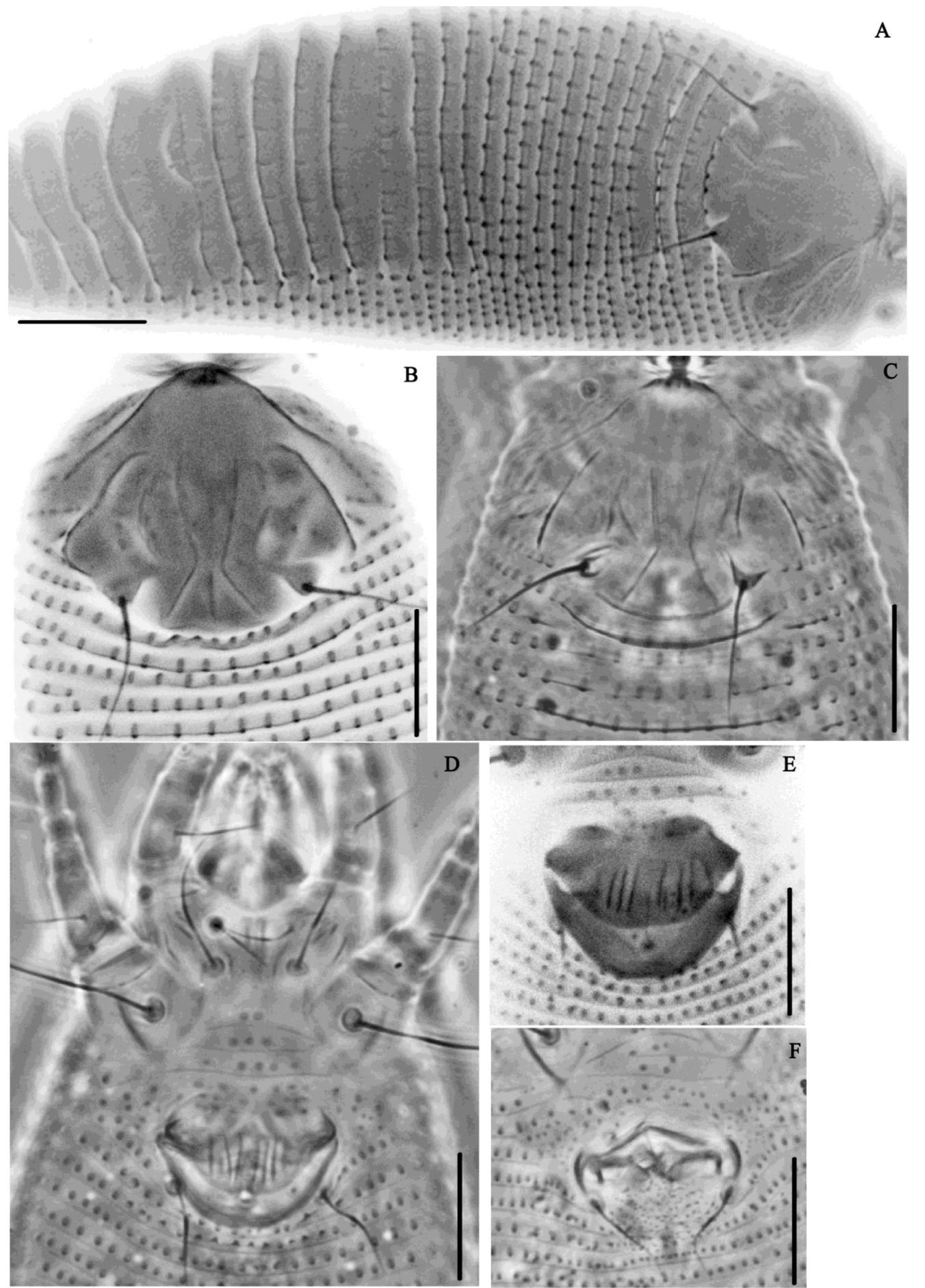

FIGURE 6. CLSM autofluorescent (A, B, E) and PC LM (C, D, F) images of Paraphytoptus serenus sp. nov. (A) dorsal view, female, (B, C) prodorsal shield; (D) coxigenital region, female, (E) external genitália, female (F) external genitalia, male. Scale bar: $20 \mu \mathrm{m}$. 
Family Eriophyidae Nalepa 1898

Subfamily Phyllocoptinae Nalepa 1892

Tribe Anthocoptini Amrine \& Stasny 1994

Genus Tegoprionus Keifer 1961

Diagnosis. Anthocoptines (sensu Amrine et al. 2003) with one midlongitudinal dorsal opisthosomal ridge; dorsal annuli irregularly bearing a wide central lobe projecting dorsally. Each dorsal annulus covers 3-4 ventral annuli, laterally.

Remarks. This new anthocoptine species is close to Heterotergum Keifer 1955 and Tegoprionus Keifer 1961; morphologically it is closer to Tegoprionus, that's why we provisionally place it in this genus. In Heterotergum the first 3-10 annuli posterior to shield margin are narrower than the dorsal annuli and microtuberculate, forming complete rings around opisthosoma (in the new species all dorsal annuli are smooth and distinctly broader than ventral annuli). Tegoprionus possesses one midlongitudinal dorsal opisthosomal ridge; dorsal annuli irregularly bearing a wide central lobe projecting dorsally; each dorsal annulus covers 3-4 ventral annuli, laterally. In comparison to previously described Tegoprionus mites (T. dentatus (Nalepa, 1891) and T. mesogibbosus Flechtmann \& Amrine 2014) the new species possesses the first 7-9 dorsal annuli evenly arched, followed by 4-6 broader and strongly arched annuli, no lobe projecting dorsally. The new species does not precisely fit to diagnosis of none of the two genera (Tegoprionus and Heterotergum) indicating that current criteria used for delimitating anthocoptine genera are imperfect. It is possible, that the new species represents a new genus. Further faunistic and molecular phylogenetic studies could uncover diversity of similar Tegoptionus-like species and clarify this taxonomic position.

Tegoprionus alobus sp. nov. Duarte, Chetverikov \& Navia (Figs. 7-9 and 10 F-H, Tables 3, 4 and 5)

Description. Female ( $\mathrm{n}=10)$. Idiosoma fusiform, 213 (181-224) long, 58 (50-61) wide, yellowish. Gnathosoma 21(19-22) long, projecting downwards; pedipalp coxal seta (ep) 2, dorsal pedipalp genual seta $(d) 5$ (4-5); chelicerae 20 (19-21) long; auxiliary stylet 16 (14-17) long. Prodorsal shield 35 (32- 37) long, 46 (42-49) wide, triangular; prodorsal shield ornamentation indistinct; median line absent, faint admedian lines present in rear half of the shield (better seen under CLSM), three-five longitudinal rows of microtubercles or short dashes present in anterior third of prodorsal shield; a diagonal subdorsal line can be traced following microtuberles situated in the lateral area of prodorsal shield; epicoxal area with tiny microtuberles; frontal lobe slightly rounded anteriorly, 4 (45) long, 13 (11-13) wide; scapular tubercles on rear shield margin, 27 (24-27) apart, scapular setae (sc) 27 (22-27) long, directed backward and diverging, reaching the 4th (4th-5th) dorsal annulus. Coxigenital region with 1 (1-2) incomplete annuli and 3 (2-3) complete annuli, microtuberculate. Coxisternal plates. Prosternal apodeme 8 (6-8) long, anterior seta on coxisternum I (1b) 8 (8-10) long, 9 (9-10) apart; proximal seta on coxisternum I (1a) 27 (21-27) long, 10 (8-10) apart; proximal seta on coxisternum II (2a) 47 (30-47) long, 24 (21-24) apart. Leg I 30 (27-30) long, femur 6 (6$7)$, ventral basifemoral seta $(b v) 11(9-12)$; genu 5 (4-5), antaxial genual seta $\left(l^{\prime \prime}\right) 21$ (18-22); tibia 6 (5-7), paraxial tibial seta $\left(l^{\prime}\right) 7(4-7)$; tarsus 7 (6-8), antaxial fastigial tarsal seta $\left(f t^{\prime \prime}\right) 21$ (16-22), paraxial fastigial tarsal seta $\left(f t^{\prime}\right) 19$ (13-19), paraxial unguinal tarsal seta $\left(u^{\prime}\right) 4(3-4)$, empodium 6 (5-6) long, 4-rayed, tarsal solenidion ( $\omega) 9$ (7-9), slightly curved, blunt. Leg II 26 (24-27) long, femur 7 (6-8), ventral basifemoral seta $(b v) 11$ (8-12); genu 4 (3-4), antaxial genual seta $\left(l^{\prime \prime}\right) 9$ (6$9)$; tibia 4 (4-5); tarsus 6 (5-7), antaxial fastigial tarsal seta $\left(f t^{\prime \prime}\right) 21$ (17-22), paraxial fastigial tarsal seta $\left(f t^{\prime}\right) 6(4-7)$, paraxial unguinal tarsal seta $\left(u^{\prime}\right) 4$ (3-4), empodium 5 (5-6) long, 4 (4)-rayed, tarsal solenidion ( $\omega) 10$ (7-10), slightly curved, blunt. Opisthosoma with 19 (17-23) dorsal annuli, 
smooth; first 7 (7-9) annuli evenly arched, next 4 (4-6) annuli broader and strongly arched, no lobe projecting dorsally and posterior 6 (6-7) annuli evenly arched; 59 (59-66) ventral annuli microtuberculate. Seta $c 220$ (14-22), on ventral annulus 5 (5-6); seta $d 51$ (41-51) long, 40 (30-45) apart, 23 (21-26) microtubercles apart, on ventral annulus 18 (18-21); seta $e$ 12 (7-12) long, 20 (1823) apart, 11 (9-13) microtubercles apart, on ventral annulus 34-35 (34-38); seta $f 20$ (17-20) long, 15 (10-16) apart, 8 (7-9) microtubercles apart, on ventral annulus 54 (54-61). Seta $h_{1} 2(2-3), h_{2} 58$ (47-58). Female genitalia 15 (14-16) long, 20 (17-20) wide, genital coverflap with 10 (10-13) longitudinal ridges and 2-3 basal transversal lines; setae $3 a 20$ (16-20) long.

TABLE 3. Main morphological differences among Tegoprionus species

\begin{tabular}{|c|c|c|c|}
\hline Characters & Tegoprionus alobus sp. nov. & $\begin{array}{c}\text { Tegoprionus dentatus (Nalepa, } \\
1891 \text { ) }\end{array}$ & $\begin{array}{l}\text { Tegoprionus mesogibbosus } \\
\text { Flechtmann \& Amrine } 2014\end{array}$ \\
\hline Dorsal annuli & $\begin{array}{l}\text { 4-6 dorsal annuli broader and } \\
\text { strongly arched, no lobe } \\
\text { projecting dorsally }\end{array}$ & $\begin{array}{l}\text { Dorsal annuli irregularly bearing a } \\
\text { wide central lobe projecting } \\
\text { dorsally }\end{array}$ & $\begin{array}{l}4 \text { dorsal annuli each with a large } \\
\text { dorsomedian enlargement }\end{array}$ \\
\hline Prodorsal shield ornamentation & $\begin{array}{l}\text { With microtubercles or short } \\
\text { dashes placed in longitudinal } \\
\text { lines in the anteromedian area }\end{array}$ & $\begin{array}{l}\text { Apparently smooth in the median } \\
\text { shield and sparsely granulated in } \\
\text { the sublateral area }\end{array}$ & Smooth \\
\hline Number of empodium rays & 4 & 4 & $5-6$ \\
\hline Frontal lobe & Broad based and apically curved & Pointed & Broad based and apically curved \\
\hline Host and relation to host & $\begin{array}{l}\text { From } L \text {. alba } \text { (Verbenaceae); } \\
\text { vagrant on the lower leaf } \\
\text { surface; presumably associated } \\
\text { with chlorotic spots }\end{array}$ & $\begin{array}{l}\text { From Galium verum (Rubiaceae), } \\
\text { found in deformed, ball like } \\
\text { inflorescences and more rarely in } \\
\text { greenish flowers }\end{array}$ & $\begin{array}{l}\text { From Inga sessilis (Vell.) Mart. } \\
\text { (Fabaceae); vagrant on the lower leaf } \\
\text { surface; no visible damage }\end{array}$ \\
\hline Locality & Brazil & Not mentioned & Brazil \\
\hline
\end{tabular}

Male $(n=5)$. Shorter than females and generally similar to them. All measurements of males are given in Table 4. External genitalia. Subtriangular, 13-18 wide, seta 3a 15-16 long. Posterior region of the epiandrium between and behind the genital setae $3 a$ with rounded microtubercles aligned in rows or sometimes irregular (Fig. 8 and 9 F).

Host plant. Lippia alba (Mill.) N. E. Brown (Verbenaceae). Mites are vagrant on the lower leaf surface. Presumably associated with chlorotic spots.

Type material. Female holotype, 10 female paratypes, 3 males (each on a separate slide), deposited in the mite collection at Embrapa Genetic Resources and Biotechnology, Brasılia, Federal District, Brazil. Paratypes: 5 females, 1 male-(each on a separate slide), deposited in the Department of Entomology, Plant Pathology and Agricultural Zoology, ESALQ/USP, Piracicaba, São Paulo, Brazil and 10 females, 2 males (each on a separate slide) in the Acarological Collection of the Zoological Institute of Russian Academy of Sciences (ZIN RAS), Russia. All specimens from Brazil: Brasília, Federal District (15² 41' 18"S, 47 49' 39" O), 03 March 2014, coll. Duarte, M.E. and Navia, D.

Additional material. 24 mites on 11 slides collected from Brazil: Maceió, Alagoas State $\left(09^{\circ}\right.$ 32' 42"S, 35'43' 31" O), 23 May 2012 and 12 October 2013 (same host), collector Duarte, M.E. All deposited in the mite collection at Embrapa Genetic Resources and Biotechnology, Brasılia, Federal District, Brazil.

Etymology. The specific designation alobus is derived from the Latin words a "absent", lobus "lobe", referring to the absence of lobes on the dorsal annuli, which are present in the other two Tegoprionus species described. 


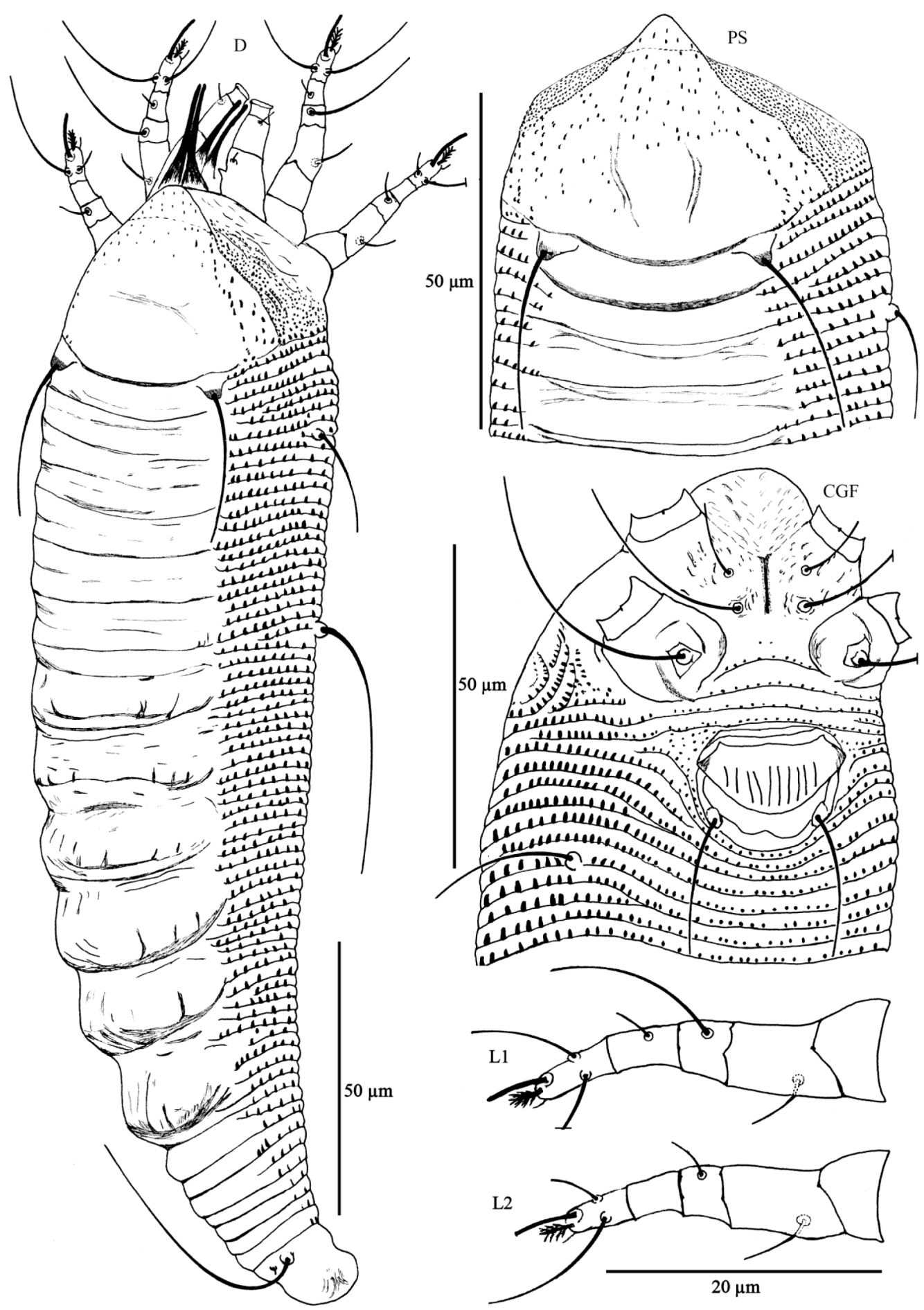

FIGURE 7. Tegoprionus alobus sp. nov.-D. Female dorsal view; PS. Prodorsal shield; CGF. Coxigenital region, female; L1. Leg I, female; L2. Leg II, female.

Differential diagnosis. The new species can be differentiated from the other two Tegoprionus species-(T. dentatus) and T. mesogibbosus), in the dorsal annuli without central lobe projecting 
dorsally; prodorsal shield ornamentation with microtubercles or short dashes placed in longitudinal lines in the anteromedian area, aligned forming a subdorsal line, and sparse in the lateral shield and in the frontal lobe broad based and apically curved.
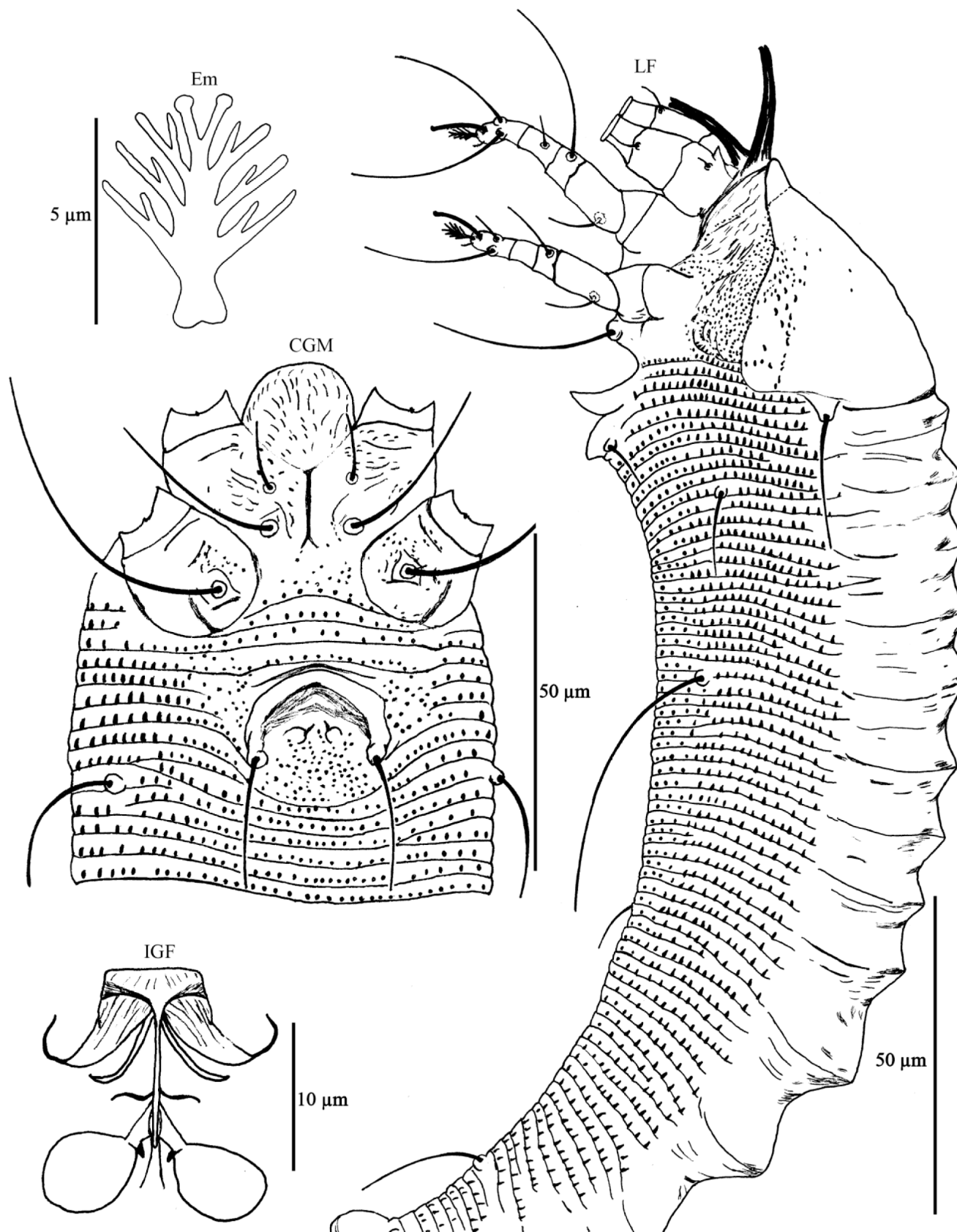

$50 \mu \mathrm{m}$
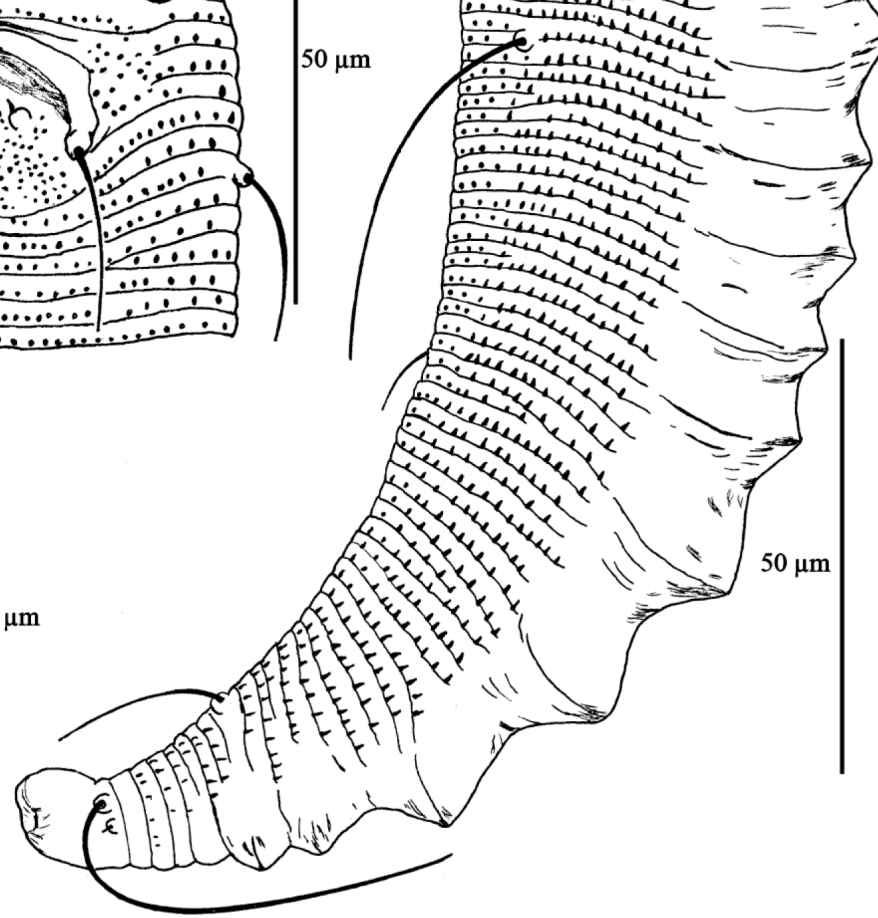

FIGURE 8. Tegoprionus alobus sp. nov.-CGM. Coxigenital region male; Em. Empodium; LF. Lateral view, female; IGF. Internal genitalia, female. 
TABLE 4. Measurements of eriophyoid mites from Lippia alba (L—length, W—width)

\begin{tabular}{|c|c|c|c|c|c|c|c|c|c|c|c|}
\hline \multirow{3}{*}{ Character } & \multicolumn{3}{|c|}{ Rhynacus lippius sp. nov. } & \multicolumn{4}{|c|}{ Paraphytoprus serenus sp. nov. } & \multicolumn{4}{|c|}{ Tegoprionus alobus sp. nov. } \\
\hline & \multicolumn{2}{|c|}{ Female $(n=10)$} & \multirow{2}{*}{$\begin{array}{l}\text { Male } \\
(\mathrm{n}=2)\end{array}$} & \multicolumn{2}{|c|}{ Female $(\mathrm{n}=10)$} & \multicolumn{2}{|c|}{ Male $(n=5)$} & \multicolumn{2}{|c|}{ Female $(n=10)$} & \multicolumn{2}{|c|}{ Male $(n=5)$} \\
\hline & $\begin{array}{l}\text { Mean } \pm \\
\text { SD }\end{array}$ & $\begin{array}{l}\text { Min- } \\
\text { Max }\end{array}$ & & $\begin{array}{r}\text { Mean } \pm \\
\text { SD }\end{array}$ & Min-Max & $\begin{array}{c}\text { Mean } \pm \\
\text { SD }\end{array}$ & $\begin{array}{l}\text { Min- } \\
\text { Max }\end{array}$ & $\begin{array}{l}\text { Mean } \pm \\
\text { SD }\end{array}$ & $\begin{array}{l}\text { Min- } \\
\text { Max }\end{array}$ & $\begin{array}{c}\text { Mean } \pm \\
\text { SD }\end{array}$ & $\begin{array}{l}\text { Min- } \\
\text { Max }\end{array}$ \\
\hline Idiosoma L. & $277 \pm 15.4$ & $246-299$ & $206-223$ & $195 \pm 11.4$ & $172-215$ & $149 \pm 7.2$ & $138-157$ & $205 \pm 15.4$ & $181-224$ & $158 \pm 5.5$ & $152-163$ \\
\hline Idiosoma W. & $73 \pm 5.7$ & $65-82$ & $61-62$ & $52 \pm 3.2$ & $48-59$ & $42 \pm 2.9$ & $38-45$ & $56 \pm 3.9$ & $50-61$ & $43 \pm 2.7$ & $40-47$ \\
\hline Prodorsal shield L. & $27 \pm 1.5$ & $24-28$ & $22-25$ & $28 \pm 0.7$ & $27-29$ & $25 \pm 1.0$ & $24-27$ & $35 \pm 1.4$ & $32-37$ & $32 \pm 0.7$ & $31-33$ \\
\hline Prodorsal shield $\mathrm{W}$. & $50 \pm 3.3$ & $44-53$ & $40-42$ & $35 \pm 2.2$ & $31-39$ & $34 \pm 2.5$ & $31-38$ & $46 \pm 2.4$ & $42-49$ & $39 \pm 1.9$ & $37-41$ \\
\hline Scapular seta $(s c) \mathrm{L}$. & - & - & - & $18 \pm 0.7$ & $17-19$ & $15 \pm 0.6$ & $15-16$ & $24 \pm 1.8$ & $22-27$ & $26 \pm 3.9$ & $20-29$ \\
\hline $\begin{array}{l}\text { Scapular tubercle } \\
\text { apart }\end{array}$ & $23-1.2$ & $22-25$ & $21-22$ & $15 \pm 0.6$ & $14-16$ & $14 \pm 1.3$ & $13-16$ & $26 \pm 1.0$ & $24-27$ & $24 \pm 0.7$ & $23-25$ \\
\hline $\begin{array}{l}\text { Annuli reached by the } \\
\text { seta } s c\end{array}$ & - & - & - & $5 \pm 0.4$ & $5-6$ & $6 \pm 0.5$ & $5-6$ & $4 \pm 0.4$ & $4-5$ & $5 \pm 0.5$ & $4-5$ \\
\hline Frontal lobe L. & - & - & - & $2 \pm 0.0$ & 2 & $2 \pm 0.3$ & $2-3$ & $5 \pm 0.4$ & $4-5$ & $5 \pm 0.4$ & $4-5$ \\
\hline $\begin{array}{l}\text { Frontal lobe (base) } \\
\text { W. }\end{array}$ & - & - & - & $7 \pm 0.7$ & $6-8$ & $7 \pm 0.9$ & $6-9$ & $12 \pm 0.7$ & $11-13$ & $11 \pm 1.2$ & $9-12$ \\
\hline Gnathosoma L. & $40 \pm 4.0$ & $35-48$ & $32-39$ & $17 \pm 0.8$ & 16-19 & $17 \pm 0.8$ & $15-18$ & $20 \pm 0.8$ & $19-22$ & $19 \pm 0.7$ & $18-19$ \\
\hline $\begin{array}{l}\text { Dorsal pedipalp } \\
\text { genual seta }(d)\end{array}$ & - & - & - & $3 \pm 0.4$ & $3-4$ & $4 \pm 0.7$ & $3-5$ & $5 \pm 0.5$ & $4-5$ & $4 \pm 0.5$ & $3-5$ \\
\hline $\begin{array}{l}\text { Pedipalp coxal seta } \\
(e p)\end{array}$ & $2 \pm 0.2$ & $1-2$ & $1-2$ & $2 \pm 0.1$ & $2-2$ & $2 \pm 0.1$ & $2-2$ & $2 \pm 0.0$ & 2 & $2 \pm 0.1$ & $2-2$ \\
\hline Chelicerae L. & $70 \pm 2.2$ & $67-74$ & $56-65$ & $17 \pm 0.6$ & $16-18$ & $15 \pm 1.0$ & $14-16$ & $19 \pm 0.6$ & $19-21$ & $18 \pm 0.6$ & $17-19$ \\
\hline Auxiliary stylet L. & $57 \pm 2,3$ & $53-60$ & $48-48$ & $12 \pm 1.3$ & $10-14$ & $11 \pm 0.9$ & $10-12$ & $15 \pm 1.1$ & $14-17$ & $13 \pm 1.5$ & $11-14$ \\
\hline Leg I L. & $39 \pm 1.8$ & $35-41$ & $33-34$ & $24 \pm 0.9$ & $22-25$ & $22 \pm 1.4$ & $21-24$ & $29 \pm 1.2$ & $27-30$ & $27 \pm 1.4$ & $25-29$ \\
\hline Femur I L. & $9 \pm 0.8$ & $8-10$ & $8-8$ & $6 \pm 0.5$ & $5-6$ & $5 \pm 0.3$ & $5-6$ & $7 \pm 0.4$ & $6-7$ & $6 \pm 0.4$ & $6-6$ \\
\hline $\begin{array}{l}\text { Ventral basifemoral I } \\
(b v) \text { L. }\end{array}$ & - & - & - & $9 \pm 0.9$ & $7-9$ & $7 \pm 0.7$ & $6-8$ & $11 \pm 0.8$ & $9-12$ & $10 \pm 0.8$ & $9-11$ \\
\hline Genu I L. & $6 \pm 0.8$ & $5-7$ & $5-5$ & $4 \pm 0.0$ & 4 & $3 \pm 0.1$ & $3-3$ & $5 \pm 0.3$ & $4-5$ & $4 \pm 0.3$ & $4-4$ \\
\hline $\begin{array}{l}\text { Antaxial genual I }\left(l^{\prime \prime}\right) \\
\text { L. }\end{array}$ & $33 \pm 2.6$ & $30-38$ & $28-29$ & $18 \pm 2.0$ & $15-21$ & $15 \pm 1.3$ & $14-17$ & $19 \pm 1.3$ & $18-22$ & $15 \pm 1.9$ & $13-17$ \\
\hline Tibia I L. & $7 \pm 0.7$ & $6-8$ & $6-7$ & $4 \pm 0.2$ & $4-5$ & $4 \pm 0.4$ & $3-4$ & $6 \pm 0.4$ & $5-7$ & $6 \pm 0.2$ & $6-6$ \\
\hline Paraxial tibial I $\left(l^{\prime}\right) \mathrm{L}$. & $2 \pm 0.5$ & $1-3$ & $2-3$ & $4 \pm 0.6$ & $3-4$ & $4 \pm 0.3$ & $3-4$ & $6 \pm 1.0$ & $4-7$ & $5 \pm 0.5$ & $4-5$ \\
\hline Tarsus I. L. & $10 \pm 1.8$ & $9-12$ & $9-10$ & $6 \pm 0.6$ & $5-7$ & $6 \pm 0.4$ & $5-6$ & $7 \pm 0.4$ & $6-8$ & $6 \pm 0.6$ & $6-7$ \\
\hline $\begin{array}{l}\text { Paraxial fastigial } \\
\text { tarsal I }\left(f t^{\prime}\right) \text { L. }\end{array}$ & $30 \pm 1.7$ & $27-33$ & $19-28$ & $15 \pm 1.1$ & $14-18$ & $16 \pm 0.8$ & $15-17$ & $15 \pm 1.9$ & $13-19$ & $12 \pm 1.8$ & $10-14$ \\
\hline $\begin{array}{l}\text { Antaxial fastigial seta } \\
\text { I }\left(f t^{\prime \prime}\right) \text { L. }\end{array}$ & $33 \pm 2.0$ & $29-36$ & $26-30$ & $20 \pm 1.0$ & $19-22$ & $17 \pm 2.0$ & $14-19$ & $20 \pm 1.9$ & $16-22$ & $19 \pm 1.6$ & $17-21$ \\
\hline $\begin{array}{l}\text { Paraxial unguinal I } \\
\left(u^{\prime}\right) \text { L. }\end{array}$ & $6 \pm 0.4$ & & 7 & $5-6$ & $4 \pm 0.4$ & $3-4$ & $4 \pm 0.5$ & $3-4$ & $4 \pm 0.3$ & $3-4$ & $4 \pm 0.4$ \\
\hline Tarsal solenidion I L. & $7 \pm 0.4$ & & -7 & $6-7$ & $14 \pm 1.2$ & $12-15$ & $12 \pm 1.1$ & $11-14$ & $8 \pm 0.8$ & $7-9$ & $8 \pm 1.2$ \\
\hline Empodium I. L. & $9 \pm 0.6$ & & 10 & $8-9$ & $6 \pm 0.2$ & $5-6$ & $5 \pm 0.1$ & $5-5$ & $6 \pm 0.3$ & $5-6$ & $5 \pm 0.1$ \\
\hline Empodium I rays & $5 \pm 0.5$ & & 6 & $5-5$ & $4 \pm 0.0$ & 4 & $4 \pm 0.0$ & $4-4$ & $4 \pm 0.0$ & 4 & $4 \pm 0.0$ \\
\hline Leg II L. & $34 \pm 1.7$ & & -36 & $29-31$ & $21 \pm 1.2$ & $19-23$ & $19 \pm 1.1$ & $18-21$ & $26 \pm 0.9$ & $24-27$ & $24 \pm 0.5$ \\
\hline Femur II L. & $8 \pm 0.6$ & & 9 & $7-8$ & $5 \pm 0.4$ & $4-6$ & $5 \pm 0.2$ & $5-5$ & $7 \pm 0.5$ & $6-8$ & $6 \pm 0.3$ \\
\hline $\begin{array}{l}\text { Basifemoral seta II } \\
(b v) \text { L. }\end{array}$ & - & & . & - & $7 \pm 0.6$ & $6-8$ & $6 \pm 0.5$ & $6-7$ & $10 \pm 1.2$ & $8-12$ & $8 \pm 1.4$ \\
\hline Genu II L. & $4 \pm 0.5$ & & 5 & $3-3$ & $3 \pm 0.0$ & 3 & $3 \pm 0.1$ & $3-3$ & $4 \pm 0.3$ & $3-4$ & $3 \pm 0.3$ \\
\hline Genual seta II $\left(l^{\prime}\right)$ L. & - & & . & - & $6 \pm 0.6$ & $5-7$ & $6 \pm 0.7$ & $5-7$ & $8 \pm 1.3$ & $6-9$ & $6 \pm 1.2$ \\
\hline Tibia II L. & $6 \pm 0.5$ & & 6 & $5-5$ & $3 \pm 0.2$ & $3-4$ & $3 \pm 0.2$ & $3-3$ & $4 \pm 0.3$ & $4-5$ & $4 \pm 0.2$ \\
\hline
\end{tabular}

......continued on the next page 


\begin{tabular}{|c|c|c|c|c|c|c|c|c|c|c|c|}
\hline \multirow{3}{*}{ Character } & \multicolumn{3}{|c|}{ Rhynacus lippius sp. nov. } & \multicolumn{4}{|c|}{ Paraphytoprus serenus sp. nov. } & \multicolumn{4}{|c|}{ Tegoprionus alobus sp. nov. } \\
\hline & \multicolumn{2}{|c|}{ Female $(n=10)$} & \multirow{2}{*}{ 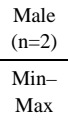 } & \multicolumn{2}{|c|}{ Female $(\mathrm{n}=10)$} & \multicolumn{2}{|c|}{ Male $(\mathrm{n}=5)$} & \multicolumn{2}{|c|}{ Female $(\mathrm{n}=10)$} & \multicolumn{2}{|c|}{ Male $(n=5)$} \\
\hline & $\begin{array}{c}\text { Mean } \pm \\
\text { SD }\end{array}$ & $\begin{array}{r}\text { Min } \\
\text { Ma }\end{array}$ & & $\begin{array}{r}\text { Mean } \pm \\
\text { SD }\end{array}$ & Min-Max & $\begin{array}{c}\text { Mean } \pm \\
\text { SD }\end{array}$ & $\begin{array}{l}\text { Min- } \\
\text { Max }\end{array}$ & $\begin{array}{c}\text { Mean } \pm \\
\text { SD }\end{array}$ & $\begin{array}{l}\text { Min- } \\
\text { Max }\end{array}$ & $\begin{array}{c}\text { Mean } \pm \\
\text { SD }\end{array}$ & $\begin{array}{l}\text { Min- } \\
\text { Max }\end{array}$ \\
\hline Tarsus II $\mathrm{L}$. & $11 \pm 1.0$ & \multicolumn{2}{|c|}{$10-13$} & $7-9$ & $5 \pm 0.7$ & $4-6$ & $5 \pm 0.4$ & $5-6$ & $6 \pm 0.6$ & $5-7$ & $6 \pm 0.4$ \\
\hline $\begin{array}{l}\text { Paraxial seta II }\left(f t^{\prime}\right) \\
\text { L. }\end{array}$ & $8 \pm 1.1$ & \multicolumn{2}{|c|}{$7-10$} & $7-7$ & $5 \pm 0.7$ & $4-6$ & $5 \pm 0.5$ & $4-5$ & $6 \pm 0.9$ & $4-7$ & $4 \pm 0.5$ \\
\hline $\begin{array}{l}\text { Antaxial seta II }\left(f t^{\prime \prime}\right) \\
\text { L. }\end{array}$ & $34 \pm 1.2$ & \multicolumn{2}{|c|}{$32-36$} & $26-29$ & $19 \pm 1.3$ & $17-20$ & $18 \pm 1.2$ & $17-20$ & $19 \pm 1.7$ & $17-22$ & $18 \pm 1.4$ \\
\hline $\begin{array}{l}\text { Unguinal seta II }\left(u^{\prime}\right) \\
\text { L. }\end{array}$ & $6 \pm 0.5$ & \multicolumn{2}{|c|}{$5-7$} & $5-5$ & $3 \pm 0.4$ & $3-4$ & $3 \pm 0.4$ & $3-3$ & $3 \pm 0.3$ & $3-4$ & $3 \pm 0.2$ \\
\hline Solenidion II L. & $7 \pm 0.8$ & \multicolumn{2}{|c|}{$7-9$} & $8-8$ & $12 \pm 1.0$ & $11-14$ & $12 \pm 1.5$ & $11-14$ & $9 \pm 0.9$ & $7-10$ & $9 \pm 0.9$ \\
\hline Empodium II L. & $9 \pm 0.8$ & \multicolumn{2}{|c|}{$8-10$} & $8-9$ & $6 \pm 0.3$ & $5-6$ & $5 \pm 0.2$ & $5-5$ & $5 \pm 0.4$ & $5-6$ & $5 \pm 0.4$ \\
\hline Empodium II rays & $5 \pm 0.4$ & \multicolumn{2}{|c|}{$5-6$} & $5-5$ & $4 \pm 0.0$ & 4 & $4 \pm 0.0$ & 4-4 & $4 \pm 0.0$ & 4 & $4 \pm 0.0$ \\
\hline Seta $l b \mathrm{~L}$. & - & \multicolumn{2}{|c|}{-} & - & $8 \pm 0.8$ & $7-10$ & $6 \pm 0.7$ & $5-7$ & $9 \pm 0.5$ & $8-10$ & $7 \pm 1.0$ \\
\hline Distance between $l b$ & - & \multicolumn{2}{|c|}{-} & - & $8 \pm 0.4$ & $7-9$ & $7 \pm 0.8$ & $6-7$ & $9 \pm 0.4$ & $9-10$ & $8 \pm 0.4$ \\
\hline Seta $l a \mathrm{~L}$. & $31 \pm 2.9$ & \multicolumn{2}{|c|}{$26-35$} & $26-28$ & $21 \pm 2.2$ & $18-24$ & $16 \pm 1.4$ & $14-17$ & $24 \pm 2.0$ & $21-27$ & $21 \pm 1.2$ \\
\hline Distance between $1 a$ & $11 \pm 1.0$ & \multicolumn{2}{|c|}{$11-14$} & $9-10$ & $9 \pm 0.9$ & $8-11$ & $8 \pm 0.6$ & $7-9$ & $9 \pm 0.6$ & $8-10$ & $8 \pm 0.5$ \\
\hline Seta $2 a \mathrm{~L}$. & $61 \pm 5.2$ & \multicolumn{2}{|c|}{$54-67$} & $40-45$ & $36 \pm 2.6$ & $31-39$ & $29 \pm 3.7$ & $25-34$ & $39 \pm 5.8$ & $30-47$ & $36 \pm 1.9$ \\
\hline Distance between $2 a$ & $27 \pm 2.6$ & \multicolumn{2}{|c|}{$22-32$} & $22-25$ & $23 \pm 1.0$ & $20-24$ & $18 \pm 2.4$ & $14-20$ & $23 \pm 1.3$ & $21-24$ & $20 \pm 0.7$ \\
\hline $\begin{array}{l}\text { Prosternal apodeme } \\
\text { L. }\end{array}$ & $12 \pm 1.3$ & \multicolumn{2}{|c|}{$9-13$} & $9-10$ & $7 \pm 0.7$ & $6-8$ & $6 \pm 0.8$ & $5-7$ & $7 \pm 0.5$ & $6-8$ & $7 \pm 0.2$ \\
\hline $\begin{array}{l}\text { Coxisternal } \\
\text { incomplete annuli }\end{array}$ & $3 \pm 0.3$ & $2-3$ & $2-3$ & $2 \pm 0.5$ & $1-2$ & $1 \pm 0.7$ & $1-2$ & $2 \pm 0.3$ & $1-2$ & $3 \pm 0.0$ & $3-3$ \\
\hline $\begin{array}{l}\text { Coxisternal } \\
\text { complete annuli }\end{array}$ & $3 \pm 0.3$ & $2-3$ & 2 & $3 \pm 0.5$ & $2-3$ & $2 \pm 1.0$ & $2-3$ & $3 \pm 0.5$ & $2-3$ & $1 \pm 0.4$ & $1-2$ \\
\hline Genitalia L. & $24 \pm 1.0$ & $22-25$ & - & $13 \pm 0.7$ & $12-14$ & - & - & $15 \pm 0.5$ & $14-16$ & - & - \\
\hline Genitalia W. & $27 \pm 1.0$ & $25-29$ & $20-22$ & $19 \pm 0.5$ & $18-20$ & $16 \pm 1.2$ & $15-18$ & $19 \pm 0.9$ & $17-20$ & $16 \pm 2.0$ & $13-18$ \\
\hline Longitudinal ribs & $8 \pm 0.6$ & $7-9$ & - & $8 \pm 0.5$ & $8-9$ & - & - & $12 \pm 0.9$ & $10-13$ & - & - \\
\hline Seta $3 a \mathrm{~L}$. & $10 \pm 1.1$ & $9-11$ & $7-8$ & $12 \pm 1.4$ & $10-14$ & $9 \pm 0.9$ & $8-11$ & $18 \pm 1.1$ & $16-20$ & $15 \pm 0.4$ & $15-16$ \\
\hline Seta $c 2 \mathrm{~L}$. & - & - & - & $19 \pm 1.7$ & $17-22$ & $17 \pm 2.1$ & $15-20$ & $19 \pm 2.5$ & $14-22$ & $18 \pm 1.1$ & $17-20$ \\
\hline Seta $c_{2}$ on annuli & - & - & - & $4 \pm 0.4$ & $4-5$ & $3 \pm 0.6$ & $3-4$ & $5 \pm 0.5$ & $5-6$ & $4 \pm 0.5$ & $3-4$ \\
\hline Seta $d \mathrm{~L}$. & $85 \pm 4.5$ & $79-93$ & $64-67$ & $36 \pm 2.2$ & $33-40$ & $27 \pm 2.5$ & $25-30$ & $46 \pm 3.5$ & $41-51$ & $43 \pm 0.8$ & $42-44$ \\
\hline Distance between $d$ & $55 \pm 4.7$ & $49-62$ & $39-42$ & $41 \pm 3.1$ & $38-48$ & $33 \pm 2.3$ & $31-36$ & $38 \pm 5.0$ & $30-45$ & $30 \pm 0.9$ & $29-32$ \\
\hline Seta $d$ on annuli & $18 \pm 1.3$ & $16-20$ & $14-15$ & $16 \pm 0.6$ & $15-16$ & $12 \pm 1.0$ & $11-13$ & $20 \pm 1.2$ & $18-21$ & $13 \pm 0.8$ & $12-14$ \\
\hline Seta $e \mathrm{~L}$. & $14 \pm 2.0$ & $10-16$ & $9-11$ & $9 \pm 1.1$ & $7-11$ & $8 \pm 1.4$ & $6-9$ & $10 \pm 1.5$ & $7-12$ & $9 \pm 0.7$ & $9-11$ \\
\hline Distance between $e$ & $37 \pm 2.0$ & $35-41$ & $29-31$ & $24 \pm 2.5$ & $21-29$ & $20 \pm 1.4$ & $18-22$ & $21 \pm 1.4$ & $18-23$ & $16 \pm 1.2$ & $15-18$ \\
\hline Seta $e$ on annuli & $36 \pm 2.8$ & $31-40$ & $28-39$ & $30 \pm 1.4$ & $28-32$ & $25 \pm 1.4$ & $23-27$ & $35 \pm 2.3$ & $34-38$ & $27 \pm 1.3$ & $25-29$ \\
\hline Seta $f$ L. & $41 \pm 3.1$ & $37-45$ & $27-34$ & $17 \pm 1.3$ & $15-19$ & $15 \pm 1.2$ & $13-16$ & $19 \pm 0.8$ & $17-20$ & $16 \pm 1.0$ & $16-18$ \\
\hline Distance between $f$ & $28 \pm 1.9$ & $24-30$ & $18-23$ & $15 \pm 0.9$ & $13-16$ & $13 \pm 1.2$ & $12-15$ & $14 \pm 1.6$ & $10-16$ & $11 \pm 1.1$ & $10-13$ \\
\hline Seta $f$ on annuli & $66 \pm 2.8$ & $61-71$ & $54-68$ & $47 \pm 2.5$ & $42-52$ & $41 \pm 1.3$ & $40-43$ & $57 \pm 2.7$ & $54-61$ & $47 \pm 1.5$ & $45-49$ \\
\hline $\begin{array}{l}\text { Number of dorsal } \\
\text { annuli }\end{array}$ & $81 \pm 3.0$ & $77-84$ & $74-82$ & $35 \pm 1.8$ & $33-38$ & $29 \pm 1.5$ & $28-31$ & $20 \pm 2.1$ & $17-23$ & $18 \pm 1.8$ & $15-20$ \\
\hline $\begin{array}{l}\text { Number of ventral } \\
\text { annuli }\end{array}$ & $77 \pm 5.1$ & $71-81$ & $66-81$ & $51 \pm 2.5$ & $46-56$ & $45 \pm 1.3$ & $44-47$ & $62 \pm 2.7$ & $59-66$ & $52 \pm 1.5$ & $50-54$ \\
\hline Seta $h 2 \mathrm{~L}$. & $89 \pm 6.9$ & 79-99 & $64-69$ & $44 \pm 6.1$ & $33-52$ & $35 \pm 2.5$ & $32-38$ & $52 \pm 3.5$ & $47-58$ & $48 \pm 5.4$ & $41-54$ \\
\hline Seta $h l \mathrm{~L}$. & $1 \pm 0.0$ & 1 & $1-1$ & $3 \pm 0.3$ & $3-4$ & $3 \pm 0.3$ & $3-3$ & $2 \pm 0.4$ & $2-3$ & $2 \pm 0.2$ & $2-2$ \\
\hline
\end{tabular}




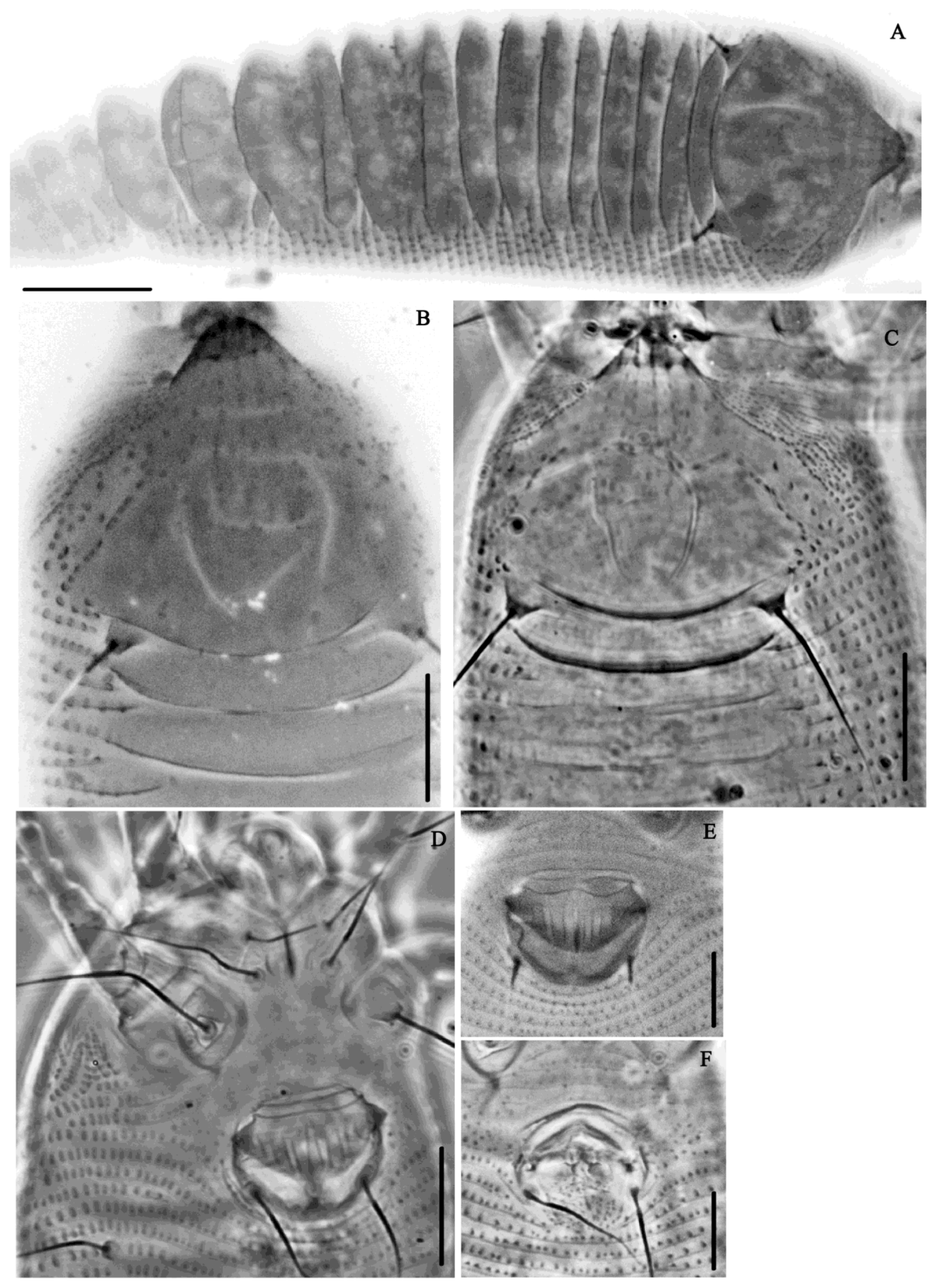

FIGURE 9. CLSM autofluorescent (A, B, E) and PC LM (C, D, F) images of Tegoprionus alobus sp. nov. (A) dorsal view, female; (B, C) prodorsal shield; (D) coxigenital region, female, (E) external genitalia, female, $(\mathrm{F})$ external genitalia, male. Scale bar: $20 \mu \mathrm{m}$. 


\section{Internal genitalia of the three new eriophyoid species (Figs. 2, 5, 8 and 10, Table 5)}

The basic characters of female internal genitalia of $R$. lippius $\mathbf{s p . ~ n o v . , ~} P$. serenus $\mathbf{s p .}$ nov. and $T$. alobus sp. nov. are similar to other eriophyoids (Chetverikov et al. 2012), including a longitudinal bridge clearly seen under the genital coverflap. Similar to all other eriophyoids except Loboquintus and Pentasetacus, the post-spermathecal part of the longitudinal bridge is reduced, sclerotized, ending with a thick, short carina (Fig. $10 \mathrm{~A}-\mathrm{H}, L B, C$ ). Anterior genital apodeme trapezoidal with longitudinal striation more or less curved (about 10 in P. serenus sp. nov. and 12 in T. alobus sp. nov.). Distinct oblique apodeme (sensu Chetverikov et al. 2015b) associated with anterior portion of pre-spermathecal part of the longitudinal bridge present under the anterior genital apodeme in all new species (Fig 10A-H, AP, OA). Spermathecal tube not segmented, almost funnel-like and sometimes with margins hard to distinguish, twisted ${ }^{1}$ in $P$. serenus sp. nov.. Spermathecal tube in $P$. serenus sp. nov. and $T$. alobus sp. nov. with sclerotized process, resembling a short stout thorn directed posterad or medioposterad and situated in the area where the tube joins the spermatheca; in $R$. lippius sp. nov. this structure is situated in the same area, but belongs to the spermatheca (Fig 10A-H, SP, TLP). Spermathecae drop-shaped, directed almost laterad or posterolaterad (in R. lippius sp. nov.) (Fig A-B, $S$ ). In $P$. serenus sp. nov. and $T$. alobus sp. nov. the spermathecae are dropshaped or pear-shaped, directed posterolaterad. Additional short perpendicular apodemes supporting plates of the longitudinal bridge were observed in these two species, however these structures were not clearly observed in $R$. lippius sp. nov. (Fig. $10 \mathrm{C}-\mathrm{H}, O A, A P A$ ). The genital chamber was observed in few specimens of $R$. lippius sp. nov. (Fig. $10 \mathrm{~A}, G C$ ).

TABLE 5. Measurements of the internal genitalic structures of females eriophyoid mites collectedfrom Lippia alba.

\begin{tabular}{|c|c|c|c|c|c|c|c|}
\hline \multirow[b]{2}{*}{ Structure } & \multirow[b]{2}{*}{ Morphometrics } & \multicolumn{2}{|c|}{$\begin{array}{c}\text { Rhynacus lippius sp. } \\
\text { nov. }(\mathrm{n}=8)\end{array}$} & \multicolumn{2}{|c|}{$\begin{array}{l}\text { Paraphytoptus serenus } \\
\text { sp. nov. }(\mathrm{n}=12)\end{array}$} & \multicolumn{2}{|c|}{$\begin{array}{c}\text { Tegoprionus alobus sp. } \\
\text { nov. }(\mathrm{n}=4)\end{array}$} \\
\hline & & Mean \pm SD & Min-max & Mean \pm SD & Min-max & Mean \pm SD & Min-max \\
\hline \multirow[t]{2}{*}{ Spermatheca } & LsI (length proximal part) & $5.8 \pm 0.7$ & $4.9-7.0$ & $6.9 \pm 0.6$ & $6.2-8.4$ & $6.2 \pm 0.9$ & $5.4-7.5$ \\
\hline & Ws (maximum width) & $5.4 \pm 0.8$ & $4.7-7.0$ & $4.8 \pm 0.45$ & $4.2-5.6$ & $5.0 \pm 0.54$ & $4.2-5.5$ \\
\hline \multicolumn{8}{|l|}{ Spermathecal tube } \\
\hline & $L t$ (length ) & $3.3 \pm 0.4$ & $2.8-3.9$ & $4.3 \pm 0.24$ & $3.8-4.6$ & $2.5 \pm 0.16$ & $2.4-2.8$ \\
\hline & Wtl (width proximal part of spermathecal tube) & $1.5 \pm 0.1$ & $1.3-1.6$ & $1.4 \pm 0.13$ & $1.2-1.7$ & $2.0 \pm 0.11$ & $1.9-2.2$ \\
\hline & Wt2(width distal part of spermathecal tube) & $2.7 \pm 0.1$ & $2.5-2.8$ & $2.2 \pm 0.25$ & $1.9-2.7$ & $1.3 \pm 0.23$ & $1.0-1.5$ \\
\hline Corniculus & (length) & $1.7 \pm 0.3$ & $1.2-2.0$ & $1.4 \pm 0.19$ & $1.1-1.8$ & $1.5 \pm 0.19$ & $1.3-1.7$ \\
\hline Longitudinal bridge & (length) & $14.7 \pm 1.2$ & $\begin{array}{c}13.4-16 \\
9\end{array}$ & $9.8 \pm 0.45$ & $9.2-10.7$ & $10.0 \pm 0.77$ & $9.0-10.8$ \\
\hline \multirow[t]{3}{*}{$\begin{array}{l}\text { Anterior (Transverse) } \\
\text { genital apodeme }\end{array}$} & WgI (apical plate width) & $8.0 \pm 0.9$ & $6.4-8.8$ & $8.4 \pm 0.59$ & $7.6-9.3$ & $7.0 \pm 0.10$ & $6.9-7.1$ \\
\hline & & & $22.9-28$ & & & & \\
\hline & Wg2 (basal width) & $25.4 \pm 1.7$ & 6 & $17.2 \pm 0.31$ & $17.0-17.8$ & $17.5 \pm 0.29$ & $17.2-17.7$ \\
\hline Oblique apodeme & (length) & $11.1 \pm 1.3$ & $9.0-13.0$ & $6.9 \pm 0.43$ & $6.3-7.6$ & $5.9 \pm 0.64$ & $5.0-6.6$ \\
\hline $\begin{array}{l}\text { Additional perpendicular } \\
\text { apodeme }\end{array}$ & (length) & - & - & $3.3 \pm 0.47$ & $2.6-4.0$ & $2.2 \pm 0.21$ & $2.1-2.5$ \\
\hline \multirow[t]{2}{*}{ Angles (in degrees, ${ }^{\circ}$ ) } & SB & $120 \pm 6.4$ & $110-128$ & $143 \pm 4.6$ & $133-149$ & $149 \pm 3.5$ & $144-154$ \\
\hline & ST & $112 \pm 7.5$ & $100-119$ & $106 \pm 7.3$ & $94-114$ & $116 \pm 4.6$ & $110-122$ \\
\hline
\end{tabular}

1. Because of several artifacts during the slide-mounting process, may be the twisted spermathecal tube is not natural. 


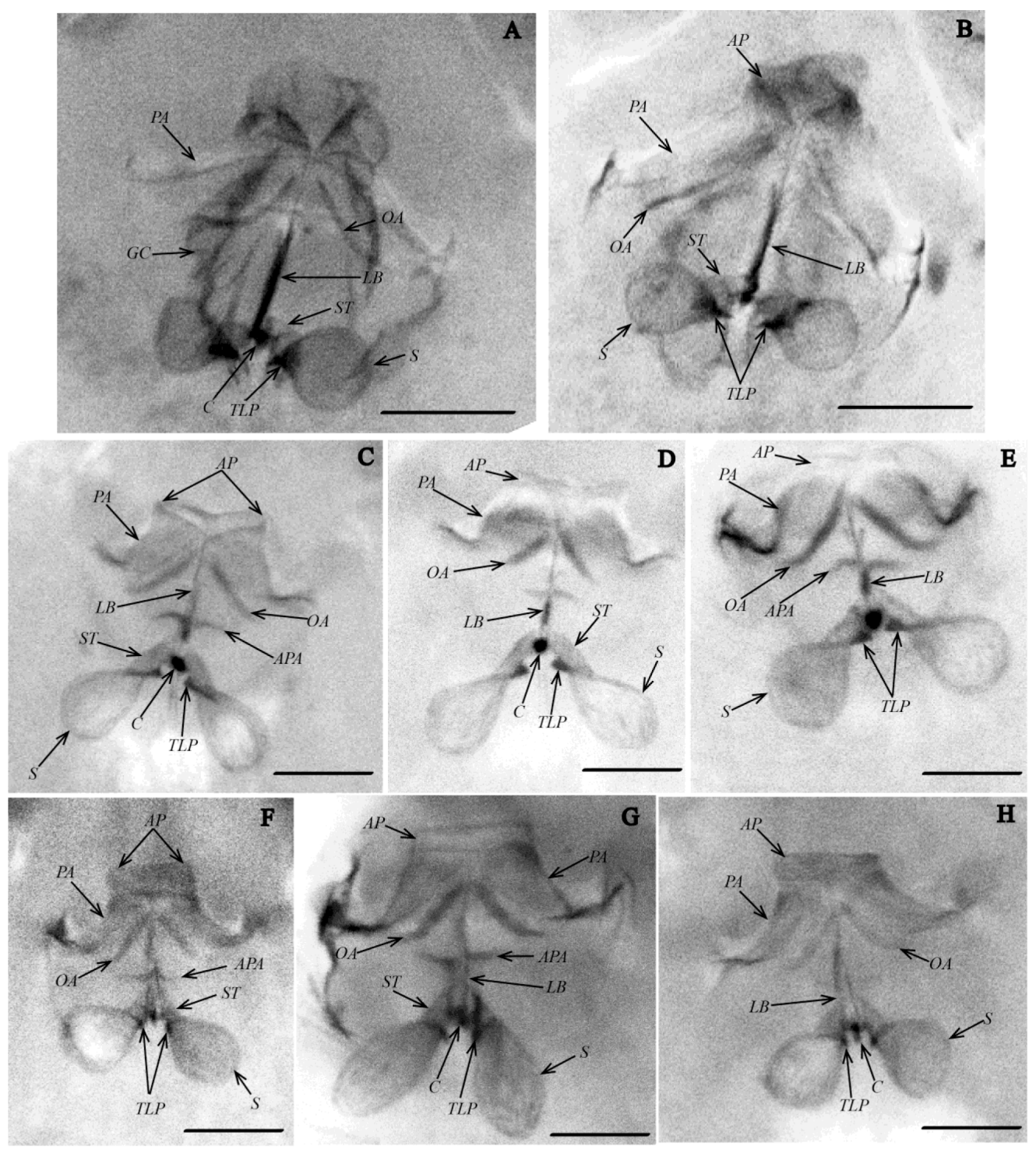

FIGURE 10. CLSM images of internal genitalia of Rhynacus lippius sp. nov. (A, B), Paraphytoptus serenus sp. nov. (C-E) and Tegoprionus alobus sp. nov. (F-H). Notation: $A P$ - apical plate of anterior genital apodeme, $A P A$-additional perpendicular apodeme, $C$ - carina (posterior part of longitudinal bridge), $G C$-genital chamber, $L B$-longitudinal bridge, $O A$ - oblique apodeme, $P A$ - posterior part of anterior genital apodeme, $S$ spermatheca, $S T$ — spermathecal tube, $T L P$ — thorn-like process. Scale bar: $10 \mu \mathrm{m}$.

\section{Discussion}

This study contributes to the taxonomic knowledge of eriophyoidea mites from Neotropical regions and also associated with verbenaceous plants. The family Verbenaceae includes several aromatic and medicinal species which are widely used in folk medicine, due to the analgesic, gastrointestinal and tranquilizing actions (Aguiar et al. 2008, Souza \& Lorenzi 2005). This family comprises around 34 
genera and 1200 species, with 480 Neotropical species and few species distributed in Europe, Asia, Africa and Madagascar (Atkins 2004). Brazil has the greatest richness of the family, with 16 genera and 290 species including 191 endemics (Salimena et al. 2016). The most representative genera in the Brazilian flora are Lippia L. (88 species, 68 endemic) (Salimena \& Múlgura 2016), and Stachytarpheta Vahl (81 species, 75 endemic) (Salimena 2016).

Information on eriophyoidea mites associated with Verbenaceae plants is scarce. Currently 63 species of eriophyoid mites associated with verbenaceous plants have been described (J.Amrine, personal database of eriophyoids, Ripka 2015). The species Rhynacus lippius sp. nov. and P. serenus sp. nov. are the first ones of the respective genera described from Brazil. Rhynacus lippius is the third Rhynacus species described from South America and the second one from Verbenaceae hosts. Tegoprionus alobus sp. nov. is the second Tegoprionus species from Brazil and the first one associated with a verbenaceous host. All the described eriophyoid mites are vagrant living under the leaf surface. Chlorotic irregular spots were observed in highly infested $L$. alba leaves. These symptoms were observed in the different collection localities where these mites were found, (Northeast and Center West Brazil). Normally, all new species can be found on the same leaf. However, Rhynacus lippius sp. nov. was the most numerous in both localities. Therefore, it is possible that this mite may be responsible for the spots, however this should be tested in future.

Recently Beaulieu et al. (2015) showed phytochemistry alterations in a medicinal plant, roseroot (Rhodiola rosea L.), due to eriophyoid mite infestation, the gall mite Aceria rhodiolae (Canestrini 1892). These authors used salidroside and rosavins as indicators and observed a significant reduction of almost half in salidroside content (45.8\%), but not in rosavins. This interesting negative effect of eriophyoid mites on composition of plants with phytotherapic properties had not been previously studied. It would be interesting to evaluate the infestation effect of the eriophyoid mites herein described on bushy lippia pharmaceutical compounds and properties.

\section{Remarks on genital anatomy of eriophyoids}

In this paper three different microscopy techniques (PC LM, DIC LM and CLSM) were used to investigate internal genitalia. These are the first detailed data of the spermathecal apparatus and associated cuticular genital structures of the representatives of three eriophyoid genera (Rhynacus, Paraphytoptus and Tegoprionus) obtained with the aid of conventional light and confocal laser scanning microscopy.

The internal genital structures of $R$. lippius sp. nov., P. serenus sp. nov. and T. alobus sp. nov. reveal significant differences as well as similarities in the shape and position of spermathecal apparatus and genital apodemes with mites from the family Phytoptidae (Chetverikov et al. 2015 and papers cited therein). Similar to mackiellines of the genera Mackiella Keifer 1939a, Retracrus Keifer 1965, Propilus Keifer 1975 and Neoprothrix Reis \& Navia 2014 (Chetverikov et al. 2014b, Chetverikov et al. 2015a, Reis et al. 2014), Paraphytoptus serenus sp. nov. and T. alobus sp. nov. present a subtrapezoidal anterior genital apodeme with two distinct part (posterior and anterior). However, the anterior part of the genital apodeme (apex) in R. lippius sp. nov. was not visible in most specimens, probably it was bent/destroyed or the slide quality was not good.

Chetverikov et al. (2015b) found that phytoptids have acute angle between spermathecal tube and longitudinal bridge (TB) in comparison to obtuse TB angle in Eriophyidae and Diptilomiopidae. In this studt, the spermathecal tube of all mites directed posterolaterad and forming an obtuse angle with longitudinal bridge (TB) $\left(93^{\circ}-149^{\circ}\right)$ (Table 5). Hence, the spermathecae are situated under the rear portion of the genital coverflap whereas in phytoptids the spermathecae are partially or entirely inserted in the space of the anterior angle of the anterior genital apodeme (in phytoptines, sierraphytoptines and novophytoptines) or situated far back from genitalia (under postgenital opistosomal annuli in nalepellinies). 
A new tiny genital structure of unknown function has been observed in all mite samples. It is a sclerotized thorn-like process in the area where the spermatheca joins the spermathecal tube, directed posterad or medioposterad; sometimes this structure is situated in the spermathecae (in R. lippius sp. nov., Figs. 10 A-B) and sometimes in the spermathecal tube (in P. serenus sp. nov. and T. alobus sp. nov., Figs. $10 \mathrm{C}-\mathrm{H}$ ). The same structure is clearly seen in many Keifer's drawings of eriophyoid mites (e.g. see figures from Baker et al. 1996). Additionally, it was recently observed under CLS microscope in several species of Cecidophyinae (S. Marinković, personal communication) and in another species of Nothopodinae, Cecidophyinae and Phyllocoptinae (Eriophyidae) and in diptilomiopid mites studied by the first and second authors. However, this structure has never been observed in Phytoptidae (Chetverikov, P. E., personal observation). Up to now, this thorn-like process has not yet been discussed in the literature. We hypothesize that presence/absence of the thorn-like process may be of high phylogenetic importance. This structure may be a synapomorphy combining several nonphytoptid suprageneric taxa in one large cluster. If this structure is present in all Eriophyidae and Diptilomiopidae it could mark the clade Eriophyidae s.l. found in molecularphylogenetic analyses by Chetverikov et al. 2015 and serve for additional separation between the two large phylogenetic lineages of eriophyoids (Eriophyidae s.l. and Phytoptidae s.l.). Further comparative studies of eriophyid and diptilomiopid spermathecal apparatus is needed to test this hypothesis.

\section{Legal requirements}

Material was collected under the Brazilian governement official authorization conceded to D. Navia and E. S. Silva by Chico Mendes Institute for Biodiversity Conservation (ICMBio), Ministry of Environment (MMA) (permanent collection permit No. 20650-1 and 32863-1, respectively). For exportation of the mite samples to Russia, an export permit was conceded by the Brazilian Institute of Environment and Renewable Natural Resources (IBAMA), Ministry of Environment (MMA), to D. Navia registered under number 15BR019152/DF.

\section{Acknowledgements}

Microscopy studies of the mites were performed in the Research Centre for Molecular and Cell Technologies and in the Centre of Microscopy and Microanalysis of Saint Petersburg State University, Russia and were supported by Russian Science Foundation (research grant 14-14-00541 to $\mathrm{PC}$ ).

To Coordenadoria de Aperfeiçoamento de Pessoal do Ensino Superior (CAPES), Fundação de Amparo a Pesquisa do Estado de Alagoas (FAPEAL), and Conselho Nacional de Desenvolvimento Científico e Tecnológico (CNPq), Brazil, for granting the fellowship to the first author M.E.D and to D.N.. To Programa de Pós-Graduação em Proteção de Plantas (CECA-UFAL). To Professor Carlos H.W. Flechtmann to provide the description and translation of Tegoprionus spp..

\section{References}

Aguiar, J.S., Costa, M.C.C.D., Nascimento, S.C. \& Sena, K.X.F.R. (2008) Atividade antimicrobiana de Lippia alba (Mill.) N. E. Brown (Verbenaceae). Brazilian Journal of Pharmacognosy, 18(3), 436-440. http://dx.doi.org/10.1590/s0102-695x2008000300018

Amrine, J.W. Jr. \& Stasny, T.A. (1994) Catalog of the Eriophyoidea (Acarina:Prostigmata) of the World. Indira Publishing House, West Bloomfield, Michigan, USA, 798 pp.

Amrine, J.W.Jr., Stasny, T.A. \& Flechtmann, C.H.W. (2003) Revised Keys to the World Genera of the Eriophyoidea 
(Acari:Prostigmata). Indira Publishing House, West Bloomfield Township, Michigan, USA, 244 pp.

Atkins, S. (2004) Verbenaceae. In: Kadereit, J.W. (ed.) The Families and Genera of Flowering Plants. Springer-Verlag, Berlin, pp. 449-468.

http://dx.doi.org/10.1007/978-3-642-18617-2_25

Baker, E.W., Kono, T., Amrine, J.W. Jr., Delfinado-Baker, M. \& Stasny, T.A. (1996) Eriophyoid mites of the United States. Indira Publishing House, West Bloomfield, 394 pp.

Beaulieu, F., Cuerrier, A., Filion, V.J., Saleem, A. \& Arnason, J.T. (2015) A gall mite, Aceria rhodiolae (Acari: Eriophyidae), altering the phytochemistry of a medicinal plant, Rhodiola rosea (Crassulaceae), in the Canadian Arctic. Journal of Natural History, 1464-5262 (Online) 1-27. http://dx.doi.org/10.1080/00222933.2015.1103910

Canestrini, G. (1892) Prospetto dell'Acarofauna Italiana. Parte Va. Famiglia dei Phytoptini (Phytoptidae). Atti della Societá Veneto-Trentina di Scienze naturali, 2 (1), 541-722.

Chandrapatya, A., Konvipasruang, P. \& Amrine, J.W. Jr. (2014) A new genus, two new species, and a new generic name of P phyllocoptine mites (Acari: Eriophyidae) infesting yang-na, Dipterocarpus alatus Roxb. ex G. Don (Dipterocarpaceae) in Thailand. Journal of the Acarological Society of Japan, 23(1), 15-28. http://dx.doi.org/10.2300/acari.23.15

Chetverikov, P.E. (2012) Confocal laser scanning microscopy technique for the study of internal genitalia and external morphology of eriophyoid mites (Acari: Eriophyoidea). Zootaxa, 3453, 56-68.

Chetverikov, P.E. (2014) Comparative confocal microscopy of internal genitalia of phytoptine mites (Eriophyoidea, Phytoptidae): new generic diagnoses reflecting host-plant associations. Experimental and Applied Acarology, 62 (2), 129-160. http://dx.doi.org/10.1007/s10493-013-9734-2

Chetverikov, P.E. (2015) Hidden diversity of endoparasitic eriophyoid mites: two new Novophytoptus Roivainen, 1947 (Acari: Eriophyoidea: Phytoptidae) species from the parenchymatous tissues of rushes (Juncaceae). Zootaxa, 4006 (3), 481-505. http://dx.doi.org/10.11646/zootaxa.4006.3.4

Chetverikov, P.E., Beaulieu, F., Cvrković, T., Vidović, B. \& Petanović, R. (2012) Oziella sibirica (Eriophyoidea: Phytoptidae), a new eriophyoid mite species described using confocal microscopy and COI barcoding. Zootaxa, 3560, 4160 .

Chetverikov, P.E., Beaulieu, F., Beliavskaia, A.Y., Rautian, M.S. \& Sukhareva, S.I. (2014a) Redescription of an earlyderivative mite, Pentasetacus araucariae (Eriophyoidea, Phytoptidae), and new hypotheses on the eriophyoid reproductive anatomy. Experimental and Applied Acarology, 63 (2), 123-155. http://dx.doi.org/10.1007/s10493-014-9774-2

Chetverikov, P.E., Craemer, C., Vishnyakov, A.E. \& Sukhareva, S.I. (2014b) CLSM anatomy of internal genitalia of Mackiella reclinata sp. nov. and systematic remarks on eriophyoid mites from the tribe Mackiellini Keifer, 1946 (Eriophyoidea, Phytoptidae). Zootaxa, 3860 (3), 261-279. http://dx.doi.org/10.11646/zootaxa.3860.3.5

Chetverikov, P.E. \& Craemer, C. (2015) Gnathosomal interlocking apparatus and remarks on functional morphology of frontal lobes of eriophyoid mites (Acariformes, Eriophyoidea). Experimental and Applied Acarology, 66,187-202. http://dx.doi. 10.1007/s10493-015-9906-3

Chetverikov, P.E., Desnitskiy, A.G. \& Navia, D. (2015a) Confocal microscopy refines generic concept of a problematic taxon: Rediagnosis of the genus Neoprothrix and remarks on female anatomy of eriophyoids (Acari: Eriophyoidea). Zootaxa, 3919 (1), 179-191.

http://dx.doi.org/10.11646/zootaxa.3919.1.8

Chetverikov, P.E., Cvrković, T., Makunin, A., Sukhareva, S., Vidović, B., \& Petanović, R. (2015b) Basal divergence of Eriophyoidea (Acariformes, Eupodina) inferred from combined partial COI and 28S gene sequences and CLSM genital anatomy. Experimental and Applied Acarology, 67 (2), 219-245. http://dx.doi.org/10.1007/s10493-015-9945-9

Craemer, C. (1996) Eriophyoidea (Acari) associated with Lantana camara L., with descriptions of two new species. African Plant Protection, 2 (1), 59-66.

de Lillo, E., Craemer, C., Amrine, J.W. Jr. \& Nuzzaci, G. (2010) Recommended procedures and techniques for morphological studies of Eriophyoidea (Acari: Prostigmata). Experimental and Applied Acarology, 51, 283-307. http://dx.doi.org/10.1007/s10493-009-9311-x

Dobrivojević, K. \& Petanović, R. (1982) Fundamentals of Acarology. Slovo Ljubve Publishing, Belgrade, Serbia, 284 pp.

Flechtmann, C.H.W. \& Amrine Jr, J.W. (2014) A new species of Tegoprionus Keifer (Prostigmata: Eriophyidae) from Brazil, described from all motile stages, with an overview of the genus Tegoprionus. Acarologia, 54 (1), 81-88. http://dx.doi.org/10.1051/acarologia/20142117 
Flechtmann, C.H.W., Ballari, M.C. \& Quintana de Quinteros, S.L. (2014) Eriophyoidea (Acari) on Solanaceous plants from Argentina, with description of a new species of Rhynacus (Diptilomiopidae) and a key to species. Systematic and Applied Acarology, 19 (1), 73-78.

http://dx.doi.org/10.11158/saa.19.1.6

Keifer H.H. (1939a) Eriophyid studies III. Bulletin of the California Department of Agriculture, 28, 144-162.

Keifer, H.H. (1939b) Eriophyid studies VII. Bulletin of the California Department of Agriculture, 28, 484-505.

Keifer, H.H. (1944) Eriophyid studies XIV. Bulletin of the California Department of Agriculture, 33, 18-38.

Keifer, H.H. (1951) Eriophyid studies XVII. Bulletin of the California Department of Agriculture, 40, 93-104.

Keifer, H.H. (1955) Eriophyid studies XXIII, Bulletin of the California Department of Agriculture, 44, 126-127.

Keifer, H.H. (1961) Eriophyid studies B-2. Bureau of Entomology of the California Department of Agriculture, 1-20.

Keifer, H.H. (1962) Eriophyid studies B-5. Bureau of Entomology of the California Department of Agriculture, 1-20.

Keifer H.H. (1965) Eriophyid studies B-16. Bureau of Entomology of the California Department of Agriculture, 1-20.

Keifer H.H. (1975) Eriophyid studies C-11. Agricultural Research Services, United States Department of Agriculture, 1-24.

Lemos, T.L.G., Matos, F.J.A., Alencar, J.W., Craveiro, A.A. \& McChesney, J.D. (1990) Antimicrobial activity of essential oil of Brazilian plants. Phytotherapy Research, 4, 82-84. http://dx.doi.org/10.1002/ptr.2650040210

Lindquist, E.E. (1996) External anatomy and systematics. 1.1.1. External anatomy and notation of structures. In: Lindquist, E.E., Sabelis, M.W. \& Bruin, J. (Eds.), Eriophyoid Mites: Their Biology, Natural Enemies and Control. World Crop Pests, 6. Elsevier Science Publishers, Amsterdam, The Netherlands, pp. 3-31. http://dx.doi.org/10.1016/S1572-4379(96)80003-0

Martins, E.R., Castro, D.M., Castellani, D.C. \& Dias, J.E. (1995) Plantas medicinais. Viçosa: UFV, 220 pp.

Nalepa, A. (1891) Neue Gallmilben. (Fortsetzung 1). Sitzungsberichte der kaiserlichen Akademie der Wissenschaften, Mathematische-Naturwissenschaftliche Klasse, Wien, 28(19), 198-199.

Nalepa, A. (1892) Neue Arten der Gattung Phytoptus Dujardin und Cecidophyes Nalepa.

Sitzungsberichte der kaiserlichen Akademie der Wissenschaften, Mathematische-Naturwissenschaftliche Klasse, Wien, 59, 525-540.

Nalepa, A. (1896) Paraphytoptus, eine neue Phytoptiden Gattung. Sitzungsberichte der kaiserlichen Akademie der Wissenschaften, Mathematische-Naturwissenschaftliche Klasse, Wien, 33(7), 55-56.

Nalepa, A. (1898) Zur Kenntniss der Gattung Trimerus Nalepa. Zoologische Jahrbücher, 11, 405-411.

Navia, D., Santos, A.S. \& Flechtmann, C.H.W. (2014) Eriophyoid mites from Brazil - An annotated check list. In: XVIth International Congress of Acarology, 2014. Abstract Book. Kyoto, 117-117.

Reis, A.C., Gondim, M.G.C. Jr., Flechtmann, C.H.W. \& Navia, D. (2014) New eriophyoid mites (Acari: Prostigmata: Eriophyoidea) from cultivated plants from northeastern Brazil, including the second taxon in the Prothricinae. Journal of Natural History, 48 (19-20), 1135-1152. http://dx.doi.org/10.1080/00222933.2013.862574

Ripka, G. (2015) A new Acaralox species (Acari: Prostigmata: Eriophyoidea) on Verbena Officinalis L. from Hungary. Acta Zoologica Academiae Scientiarum Hungaricae, 61(3), 247-254. http://dx.doi.org/10.17109/AZH.61.3.4.2015

Roivainen, H. (1947) Eriophyid news from Finland. Acta Entomolgica Fennica, 3, 1-51.

Salimena, F.R.G. (2016) Stachytarpheta. In: Lista de espécies da flora do Brasil. Jardim Botânico do Rio de Janeiro. Available from: http://floradobrasil.jbrj.gov.br/jabot/floradobrasil/FB15189. Accessed em 29 March 2014.

Salimena, F.R.G. \& Múlgura, M. (2016) Lippia. In: Lista de espécies da flora do Brasil. Jardim Botânico do Rio de Janeiro. Available from: http://floradobrasil. jbrj.gov.br/jabot/floradobrasil/FB15170. Accessed 29 March 2016.

Salimena, F.R.G., Thode, V., Mulgura, M., O'Leary, N., França, F., Silva, T.R.S. \& Souza, V.C. (2016) Verbenaceae. In: Lista de espécies da flora do Brasil. Jardim Botânico do Rio de Janeiro. Available from: http://floradobrasil.jbrj.gov.br/jabot/floradobrasil/ FB246. Accessed 29 March 2016.

Souza, V.C. \& Lorenzi, H. (2005) Botânica sistemática: Guia ilustrado para identificação das famílias de Angiospermas da flora brasileira, baseado em APG II. Plantarum, Nova Odessa, 640 pp.

Umapathy, G. (1999) Description of new species of eriophyid mites (Acari: Eriophyidae: Phyllocoptinae) from South India. Indian Journal of Acarology, 15(1-2), 99-105.

Vale, T.G, Matos, F.J.A, Lima, T.C.M. \& Viana, G.S.B. (1999) Behavioral effects of essential oils from Lippia alba (Mill.) N.E. Brown chemotypes. Journal Ethnopharmacology, 167, 127-33. http://dx.doi.org/10.1016/S0378-8741(98)00215-3

Wang, Z., Xue, X-F. \& Hong, X-Y. (2009) Four new species and a re-described species of the Diptilomiopinae (Acari: Eriophyoidea: Diptilomiopidae) from China. International Journal of Acarology, 35, (2), 123-132.

http://dx.doi.org/10.1080/01647950902917601

Submitted: 7 Apr. 2016; accepted by Xiao-Yue Hong: 29 Jul. 2016; published: 18 Aug. 2016 